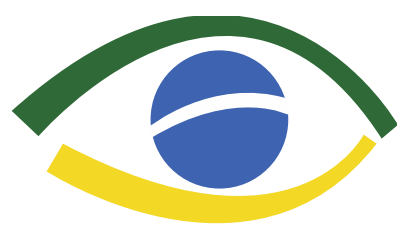

\section{Observatório da Jurisoliçãc Constitucional}

Observatório da Jurisdição Constitucional. Ano 6, no. 2, jul./dez. 2013. ISSN 1982-4564.

\title{
Sir Edward Coke, El Bonham's Case y la Judicial Review
}

Francisco Fernández Segado*

Resumen: En 1610, en el cuarto argumento del Bonham's case, Sir Edward Coke sostuvo: "Y aparece en nuestros Libros, que en muchos casos el Derecho común controla las leyes del Parlamento, y a veces debe declararlas nulas, pues cuando una ley del Parlamento es contraria al Derecho común y la razón, contradictoria o imposible de ser cumplida, el Derecho común debe tener autoridad sobre ella y declarar que tal ley es nula".

Durante casi un siglo, la doctrina científica viene debatiendo el significado del dictum de Coke, particularmente si debe entenderse como la declaración de la teoría constitucional de la revisión judicial de la legislación o, por el contrario, como la mera formulación de una máxima de la interpretación jurídica. Al margen de este debate, no cabe duda de que en la mente de los colonos americanos, primero, y en el pensamiento jurídico americano posterior a la Independencia, después, el dictum de Coke proporcionó una forma de expresión que, tratada aparte de sus otras ideas, como estaba destinado a serlo por un conjunto de jueces, comentaristas y abogados, se convirtió en la más importante fuente individual de la noción de la revisión judicial de la legislación.

El autor, atendiendo a los muy relevantes precedentes medievales; a la insuficiencia de la teoría interpretativista, entre otras razones, porque la regla de que "nadie puede ser juez en su propia causa" encarna un Derecho superior; a la comprensión del dictum en la época de Coke, y a la falta de la suficiente solidez de las objeciones opuestas frente a la teoría constitucional con base en los propios escritos de Coke, sustenta la teoría constitucional de la judicial review.

Palabras clave: Caso de Bonham. Derecho medieval. Derecho natural. Edward Coke. Parlamento ingles. Revisión judicial de la legislación.

\begin{abstract}
In 1610, in the fourth argument of the Bonham's case, Sir Edward Coke argued: "And it appears in our Books, that in many cases, the common law controls acts of Parliament, and sometimes shall adjudge them to be void: for when an act of Parliament is against common right and reason, or repugnant, or impossible to be performed, the common law will control it, and adjudge such act to be void".

For nearly a century, the scientific doctrine is discussing the meaning of the Coke's dictum, particularly if it must be understood as the declaration of the constitutional theory of the judicial review of legislation or, on the contrary, as a mere formulation of a maxim of legal interpretation. In the margin of this discussion, it is unquestionable that in the mind of the American colonists, first, and in the American legal thinking subsequent to Independence, afterwards, the dictum furnished a form of words which, treated apart from his other ideas, as it was destined to be by a series of judges, commentators, and attorneys, became the most important single source of the notion of judicial review of legislation.

The author, taking in consideration the very important medieval precedents, the insufficiency of the interpretativist theory, amongst other reasons, because the rule nemo iudex in propria causa embodies a higher law, the understanding of the dictum in the Coke's time and the lack of the sufficient soundness of the objections faced with the constitutional theory and grounded on the own writings of Coke, supports the constitutional theory of judicial review.
\end{abstract}

Keywords: Bonham's Case. Edward Coke. English Parliament. Judicial review of legislation. Medieval law. Natural law.

\footnotetext{
* Catedrático de Derecho Constitucional, Facultad de Derecho, Universidad Complutense de Madrid (UCM).
} 


\section{SUMARIO}

1. Introducción.

2. La peculiar trayectoria pública de Sir Edward Coke (1552-1634).

3. Breve aproximación al pensamiento jurídico de Coke.

4. El Case of the College of Physicians o Bonham's Case (1610). Los hechos del caso.

5. Los argumentos en que se sustenta la sentencia.

6. Los precedentes jurisprudenciales en que Coke apoya su dictum:
A) El Thomas Tregor's Case.
B) El caso Cessavit 42.
C) El caso Annuity 41.
D) El Strowd's Case.
E) Breve recapitulación sobre estos precedentes.

7. La controvertida interpretación doctrinal del célebre dictum de Coke en el cuarto argumento: ¿formulación de la teoría constitucional de la judicial review o mera enunciación de una máxima de la interpretación estatutaria?

A) Algunas consideraciones previas sobre ciertos precedentes medievales.

B) La posición proclive a ver en el pasaje de Coke una máxima de la interpretación estatutaria.

C) La posición tendente a ver en el dictum la enunciación de la teoría constitucional de la judicial review.

D) Algunas reflexiones finales propias en defensa de la teoría constitucional.

\section{Introducción.}

La doctrina jurídica viene debatiendo desde hace cerca de un siglo si el celebérrimo pasaje que se contiene en el Bonham's Case debe ser interpretado como la declaración llevada a cabo por el Juez Edward Coke de la facultad judicial de revisión de las leyes del Parlamento, que sería la resultante de la doctrina de que hay principios superiores de Derecho y justicia que las leyes parlamentarias no deben contravenir, o simplemente como la encarnación de una máxima o principio de la interpretación legal. Como ejemplos paradigmáticos de una y otra posición podemos mencionar a Plucknett y a Thorne. Para el Profesor de la "Harvard Law School", Coke adoptó su teoría de la judicial review de una

\footnotetext{
${ }^{1}$ PLUCKNETT, Theodore F. T.: "Bonham's Case and Judicial Review", en Harvard Law Review (Harv. L. Rev.), Vol. XL, 1926-1927, pp. 30 y ss.; en concreto, p. 68. Este artículo, con igual título, ha sido asimismo publicado en la obra Law, Liberty, and Parliament. Selected Essays on the Writings of Sir Edward Coke, edited
} 
práctica del siglo XIV, cubriéndola con un nuevo espíritu ("filled it with a new spirit"), producto de su propio genio. El resultado fue realmente una nueva doctrina, bien que, según pensaba el propio Coke, reforzada con precedentes indiscutibles de la Edad Media, pues Coke sabía bien que sin tal apoyo esa doctrina no habría tenido ningún valor.

Una decena de años después, Thorne, Profesor de la "Northwestern University School of Law", iba a cuestionar frontalmente la tesis de Plucknett. Thorne argumentaría, que para el Profesor de Harvard, en ninguno de los casos que se mencionaban como posibles precedentes se planteaba una cuestión constitucional, tras lo que añadía, que tampoco tal cuestión se iba a suscitar en el Bonham's case, para concluir, que "these cases, then, support no theory of higher law, binding upon Parliament and making Acts that contravene it void"2. Según Thorne, se trataba meramente de casos de strict interpretation, que parecían haber producido un resultado distinto del que pretendía el legislador.

No vamos por el momento a detenernos en la polémica, si bien sí anticiparemos que, independientemente ya de lo que Sir Edward Coke pretendiera con su dictum en el Bonham 's case, lo cierto y verdad es que en las colonias del otro lado del Atlántico tal dictum llegó a ser bien pronto una parte esencial de esa facultad de revisión judicial que iban a ejercer los tribunales americanos, anulando normas legales sobre la base de un conflicto constitucional. Como ha escrito Sherry ${ }^{3}$, “(i)t seems to be fairly widely accepted that Edward Coke was one of the primary sources of the American institution of judicial review". Más aún, el dictum de Coke, también iba a propiciar el test of reasonableness ${ }^{4}$, que es la última razón de ser del poder judicial. Innecesario es decir, que la fuerza que alienta una idea no es necesariamente objeto de medida por su verdad ${ }^{5}$.

and with an Introduction by Allen D. Boyer, Liberty Fund, Indianapolis (Indiana), 2004, pp. 150 y ss. Nuestras citas a la obra de Plucknett van referidas al artículo publicado en la Harv. L. Rev.

${ }^{2}$ THORNE, S. E.: “Dr. Bonham's Case”, en Law Quarterly Review (L. Q. Rev.), Vol. 54, 1938, pp. 543 y ss.; en concreto, p. 551.

${ }^{3}$ SHERRY, Suzanna: "Natural Law in the States", en University of Cincinnati Law Review (U. Cin. L. Rev.), Vol. 61, 1992-1993, pp. 171 y ss.; en concreto, p. 174.

${ }^{4}$ SMITH, II', George P.: "Dr. Bonham's Case and the Modern Significance of Lord Coke's Influence", en University of Washington Law Review (Wash. L. Rev.), (School of Law. University of Washington. Seattle, Washington), Vol. 41, 1966, pp. 297 y ss.; en concreto, p. 314.

En sentido análogo, BERGER, Raoul: "Doctor Bonham's Case: Statutory Construction or Constitutional Theory?", en University of Pennsylvania Law Review (U. Pa. L. Rev.), Vol. 117, 1968-1969, pp. 521 y ss.; en concreto, p. 522. 
Desde el siglo XVII, Coke, "un poeta de la sabiduría judicial y de la artesanía jurídica, antes que un profeta del cambio", como lo ha caracterizado Boyer ${ }^{6}$, uno de los autores que más ha estudiado su pensamiento, se iba a convertir en el guía y garante tanto de las asambleas como de los individuos del mundo colonial. Ya en 1657, en el caso Giddings v. Brown, el dictum de Coke iba a recibir aplicación práctica al otro lado del Atlántico. En 1721, un tal Jeremiah Dummer, un temprano autor de folletos, le utilizaba como autoridad en nombre de las colonias, en un opúsculo que fue favorablemente contemplado en vísperas de la guerra revolucionaria ${ }^{7}$. Dummer apeló a Coke como alguien que había exaltado el common law sobre las Admiralty Courts, que quitaban a los colonos sus derechos como ingleses, una cuestión, como fácilmente puede comprenderse, completamente pertinente en el período prerevolucionario.

En fin, como escribiera Corwin ${ }^{8}$, para los investigadores de los orígenes del Derecho constitucional americano ningún pronunciamiento judicial de Coke sobrepasa en interés e importancia a este dictum. Y más adelante, el propio autor iba a compendiar la contribución hecha por Coke al constitucionalismo norteamericano, a través de su dictum y del resto de su doctrina, en estos términos:

"(I)n his dictum in Bonham's Case he furnished a form of words which, treated apart from his other ideas, as it was destined to be by a series of judges, commentators, and attorneys, became the most important single source of the notion of judicial review. This is true even though we of the present day can see that, in view of the universal subordination of the common law as such to statute law, judicial review grounded simply on <common right and reason> could not have survived. But, as if in anticipation of this difficulty, Coke came forward with his second contribution, the doctrine of a law fundamental, binding Parliament and king alike, a law, moreover, embodied to great extent in a particular document and having a verifiable content in the customary procedure of everyday institutions" ". (En su dictum en el Bonham's Case, proporcionó una forma de expresión que, tratada aparte de sus otras ideas, como estaba

\footnotetext{
${ }^{6}$ BOYER, Allen Dillard: “<Understanding, Authority, and Will>: Sir Edward Coke and the Elizabethan Origins of Judicial Review”, en Boston College Law Review (B. C. L. Rev.), Vol. XXXIX, 1997-1998, pp. 43 y ss.; en concreto, p. 43.

7 MULLETT, Charles F.: "Coke and the American Revolution", en Economica (The London School of Economics and Political Science), No. 38, November, 1932, pp. 457 y ss.; en concreto, p. 468.

${ }^{8}$ CORWIN, Edward S.: "The <Higher Law> Background of American Constitutional Law" (II), en Harvard Law Review (Harv. L. Rev.), Vol. XLII, 1928-1929, pp. 365 y ss.; en concreto, p. 367.

${ }^{9}$ Ibidem, pp. 379-380.
} 
destinado a serlo por una serie de jueces, comentaristas y abogados, se convirtió en la más importante fuente individual de la noción de judicial review. Esto es cierto aun cuando nosotros, en los días actuales, podamos ver que, a la vista de la universal subordinación del common law como tal al derecho estatutario, la judicial review, fundamentada simplemente en el common right and reason, no podía haber sobrevivido. Pero, como si se anticipara a esta dificultad, Coke presentó su segunda contribución, la doctrina de un Derecho fundamental, vinculante al Parlamento y de la misma forma al rey, un Derecho, además, encarnado en gran parte en un documento concreto y que tiene un contenido verificable en el procedimiento habitual de las instituciones corrientes).

No ha de extrañar por lo hasta aquí expuesto que Jefferson, siglo y medio después, refiriéndose a la primera parte de los Institutes, aunque creemos que ello podría ampliarse a la totalidad de la obra de Edward Coke, escribiera: "Coke's Lyttleton (sic) was the universal lawbook of students, and a sounder Whig never wrote, nor of profounder learning in the orthodox doctrines of the British Constitution, or in what was called British liberties"10 (Los Comentarios de Coke sobre Littleton fueron el libro jurídico universal de los estudiantes, y nunca escribió un Whig $^{11}$ más competente, ni de un más profundo conocimiento sobre las doctrinas ortodoxas de la Constitución británica, o de lo que se llamaron las libertades británicas).

\section{La peculiar trayectoria pública de Sir Edward Coke (1552-1634).}

Nacido en el pequeño pueblo de Mileham, cercano a Norfolk, el 1 de febrero de 1552, en una familia vinculada con el Derecho (su padre era abogado), Coke se matriculó a los quince años en el Trinity College (Cambridge). Pronto ganó una excelente reputación como hábil notario $^{12}$. En 1579 ya defendió, y ganó, su primer caso ante el King 's Bench y en la década que va de 1580 a 1590, todavía a una joven edad, Edward Coke ya se había convertido en uno de los más relevantes abogados de Inglaterra $^{13}$, lo que se iba a traducir en

\footnotetext{
${ }^{10}$ Apud CORWIN, Edward S.: "The < Higher Law> Background of American Constitutional Law" (II), op. cit., p. 366.

${ }^{11}$ Los Whigs ingleses fueron un partido creado en el siglo XVII, que después sería sustituído por los liberales.

${ }^{12}$ Así lo refleja Barnes, quien habla de la reputación ganada por Coke como "a masterful conveyancer". BARNES, Thomas G.: "Introduction to Coke's <Commentary on Littleton>", en Law, Liberty, and Parliament. Selected Essays..., op. cit., pp. 1 y ss.; en concreto, p. 5.

BOYER, Allen D.: "Introduction", en Law, Liberty, and Parliament. Selected Essays..., op. cit., pp. VII y ss.; en concreto, p. VII.
} 
una rápida promoción profesional en la esfera pública. Sucesivamente, fue nombrado magistrado municipal de Coventry, Norwich y Londres, siendo elevado en 1592 al cargo de Procurador de la Corona (Solicitor General) y dos años después, compitiendo para el cargo nada menos que con Francis Bacon, su gran rival, al de Attorney General, puesto que ejercería tanto con la Reina Isabel I como con Jacobo I, quien concedería a Coke el título de "Sir".

En 1606 Coke fue nombrado Chief Justice de la Court of Common Pleas, siendo el primer juez en acceder a este tribunal sin haber ejercido con anterioridad ante el mismo como abogado. En 1613 accedió a la Presidencia del King's Bench. Aunque nominalmente este nombramiento suponía un ascenso, entrañaba más bien lo contrario (Barnes dice que supuso "a veritable kick upstairs"14), tanto desde el punto de vista de sus ingresos como de su poder; también popularmente, el cambio de órgano judicial se percibió como una reprimenda tras la que se vio una estratagema de su omnipresente enemigo Francis Bacon. Coke ostentó su nueva responsabilidad tan sólo durante tres años, siendo éste un período turbulento para él debido a sus enfrentamientos con el Rey Jacobo I (Rey de Inglaterra entre 1603 y 1625) y con el Arzobispo de Canterbury. A fines de junio de 1616, Coke fue suspendido de su puesto en el Privy Council, y el 16 de noviembre, cesado en la Chief Justiceship ${ }^{15}$.

El conflicto acaecido en 1616 entre Coke y Ellesmere, Lord Chancellor, otro de los grandes enemigos de aquél, en el que se gesta la definitiva salida de la magistratura de Coke, ha atraído la atención de los juristas durante más de tres siglos. Aunque formalmente versó sobre la insistencia de Coke en que el principio de res iudicata impedía cualquier litigio posterior in equity después de la decisión dictada por un common law court, el conflicto entrañaba mucho más que un debate sobre una cuestión puramente técnica. Como argumenta Dawson, "the conflict of 1616 represents merely one stage in a sustained attempt by judicial agencies to impose restraints on political authority" ${ }^{\prime 16}$. Con el ataque sobre la High

\footnotetext{
${ }^{14}$ BARNES, Thomas G.: "Introduction to Coke's $<$ Commentary on Littleton>", op. cit., pp. 14-15.

${ }^{15}$ Gray ha considerado el año 1616 como "a landmark in the history of English equity", a causa de lo que generalmente viene referido como la lucha de Lord Coke con la Chancery, esto es, con el Tribunal de Justicia de la Chancillería. Se suele considerar, que este enfrentamiento se resolvió por el Rey a través de su Declaración de julio de 1616 en favor de la Chancery, siendo el desencadenante último del cese de Coke en la magistratura. Recordemos tan sólo que la controversia jurídica de 1616 versó formalmente sobre la conveniencia de una intervención judicial equitativa, o en equidad ("equitable intervention"), después de una decisión judicial sustentada en el common law. Coke se mostraría absolutamente contrario a tal intervención. Cfr. al efecto, GRAY, Charles M.: "The Boundaries of the Equitable Function", en The American Journal of Legal History (Am. J. Legal Hist.), Vol. 20, 1976, pp. 192 y ss.; en concreto, p. 192.

DAWSON, John P.: "Coke and Ellesmere Disinterred: The Attack on the Chancery in 1616", en Illinois Law Review (Ill. L. Rev.), Vol. 36, 1941-1942, pp. 127 y ss.; en concreto, p. 128.
} 
Commission, los tribunales de common law invadían un área judicial de la Corona estrechamente vinculado con cuestiones vitales de la política nacional. Ya Coke, con su pronunciamiento en el Case of Proclamations, había sostenido importantes restricciones sobre la facultad de legislar por decreto real. En junio de 1616, el conflicto alcanzó su punto culminante en el Case of Commendams, en el que el Rey insistió en su facultad de aplazar aquellos procedimientos en que los intereses reales se vieran afectados, frente a lo que Coke, manifestándose en solitario ante la pasividad de los restantes jueces, se opuso, rehusando someterse a la demanda del Monarca, con lo que la ruptura con Jacobo I era ya irremediable.

Se dijo entonces, escribió John Chamberlain, que "four p's" habían echado abajo al Chief Justice: "that is, pride, prohibitions, praemunire, and prerogative" ${ }^{17}$, pero lo que parece claro después de todo lo dicho, y ha suscitado tradicionalmente el acuerdo de la doctrina ${ }^{18}$, es que el cese se debió fundamentalmente a la exasperación del Rey resultante de los varios intentos de Coke de limitar la prerrogativa real, si bien, también pudo jugar un cierto efecto la posición sustentada por nuestro Juez en otro conflictivo litigio, el Bagg's Case ${ }^{19}$.

La caída en desgracia de nuestro personaje llegó al extremo de que se le ordenara la corrección de algunos de sus Reports (a los que nos referiremos más adelante), quizá de resultas de que sus adversarios le acusaron de haber publicado en ellos "extravagant opinions" ${ }^{20}$. Sin embargo, la boda de su hija Frances con Sir John Villiers, hermano del favorito del Rey, el Duque de Buckingham, (a la que Coke se había opuesto antes de su cese) tuvo efectos balsámicos en su relación con el Monarca, retornando a su puesto en el Privy Council, aunque ya nunca volvería a ejercer funciones judiciales.

\footnotetext{
${ }^{17}$ Apud BOYER, Allen D.: "Introduction", en Law, Liberty, and Parliament. Selected Essays..., op. cit., pp. VII y ss.; en concreto, p. X.

${ }_{18}$ Así, entre otros, STONER, Jr, James R..: Common law and liberal theory. Coke, Hobbes, and the Origins of American Constitutionalism, University Press of Kansas, Lawrence (Kansas), 1992, p. 15.

${ }^{19}$ Según el informe de este caso elaborado por Coke para sus Reports, el Chief Justice consideró que el King's Bench tenía autoridad no sólo para corregir los errores en los procedimientos judiciales sino también los errores extrajudiciales; para Coke, ninguna injusticia ni daño, privado o público, que pudiera producirse quedaba exenta de reparación a través de la aplicación del Derecho. Habiendo delegado el Monarca su autoridad de impartir justicia en su Tribunal del King's Bench, ya no podía ejercerla personalmente. Sosin recuerda, que tanto Francis Bacon, entonces Attorney General, como el Lord Chancellor Ellesmere, los grandes enemigos de Coke, incluirían este pronunciamiento judicial entre los "cinco errores imperdonables" ("five unforgivable errors") de los Reports. SOSIN, J. M.: The Aristocracy of the Long Robe (The Origins of Judicial Review in America), Greenwood Press, New York/Westport, Connecticut/London, 1989, pp. 64-65.

${ }^{20}$ BOUDIN, Louis B.: "Lord Coke and the American Doctrine of Judicial Power", en New York University Law Review (N. Y. U. L. Rev.), Vol. 6, 1928-1929, pp. 223 y ss.; en concreto, p. 229.
} 
En 1621, tras una larga ausencia de casi tres décadas, Coke volvió a la House of Commons, de la que ya había sido miembro, llegando a ocupar incluso el cargo de Speaker (1593). En esta etapa se convirtió en uno de los líderes más relevantes, si es que no el que más, de la Cámara, aunque también en ella hubo de afrontar situaciones tan graves como la de ser encarcelado durante siete meses en la Torre de Londres, de resultas de la posición jurídica que defendió en el Parlamento acerca de la vigencia del Derecho establecido por quienes habían precedido al Rey Jacobo I, interpretación que le daba pie a su vez para sostener que el Parlamento seguía gozando de las prerrogativas, derechos y privilegios que históricamente le habían sido reconocidos, lo que chocaba con la visión absolutista del Monarca ${ }^{21}$. Creemos que bien se puede decir, que Coke fue encarcelado por su sistemático rechazo hacia la prerrogativa real y su defensa de las libertades parlamentarias.

Nuestro personaje volvería al Parlamento en 1624, para cesar en 1626 tras ser nombrado Gobernador (“sheriff”) de Buckingham por el nuevo Rey Carlos I. Elegido de nuevo para el Parlamento en 1628, Coke desempeñó un rol verdaderamente clave en la aprobación del trascendental texto de la Petition of Rights. Se ha subrayado ${ }^{22}$, que en este debate Coke se inclinó decididamente por identificar el fundamental law como due process.

En sus Institutes, término por cierto nada casual, pues al ponerlo, nuestro Chief Justice tenía en la cabeza la obra homónima de Justiniano (los Instituta, que junto a las Pandectas y otros textos normativos integrarían posteriormente el Corpus iuris civilis), Coke pondría un acento especial en los aspectos procedimentales. Buen ejemplo de ello lo encontramos en la segunda parte de los mismos, en la que procede a comentar los diversos capítulos de la Magna Charta. Coke siempre atribuyó una gran importancia a la Carta Magna,

\footnotetext{
${ }^{21}$ Vale la pena recordar este enfrentamiento entre Jacobo I y Coke, uno de los muchos que tuvo con el Monarca. En 1621, algunos miembros del Parlamento cuestionaron la política del Rey respecto a España y a la Iglesia Católica; el Rey les prohibió discutir con posterioridad sobre tales cuestiones. Coke y otros parlamentarios insistieron en la libertad de expresión y debate de los miembros del Parlamento, un privilegio heredado de Reinados anteriores, a lo que el Rey replicó que sus privilegios "were derived from the grace and permission of our ancestors and us (for most of them grow from precedents, which show rather a toleration than inheritancee)". A sugerencia de Coke, la House of Commons publicó en sus diarios una "Protestation", declarando, "that the liberties, franchises, privileges and jurisdictions of Parliament are the ancient and undoubted birthright and inheritance of the subjects of England". Como señala Berman, fue por esta afirmación de que el Parlamento "heredó" sus libertades como un "derecho de nacimiento", frente a la consideración regia de que las poseía por "tolerancia real", lo que condujo a Jacobo I a cesar a Edward Coke en su cargo en el Privy Council y a ordenar su encarcelamiento en la Torre de Londres, en la que permaneció confinado y virtualmente aislado durante siete meses. BERMAN, Harold J.: "The Origins of Historical Jurisprudence: Coke, Selden, Hale", en Yale Law Journal (Yale L. J.), Vol. 103, 1993-1994, pp. 1651 y ss.; en concreto, p. 1677.

22

MacKAY, R. A.: "Coke-Parliamentary Sovereignty or the Supremacy of the Law?", en Michigan Law Review (Mich. L. Rev.), Vol. XXII, 1923-1924, pp. 215 y ss.; en concreto, p. 232.
} 
lo que en el fondo era tributario de una visión simbólica o metafórica de la historia, con base a la cual la Carta Magna se visualizaba como un símbolo de la restricción del ejercicio arbitrario del poder. $\mathrm{Y}$ es bien significativo al respecto, que aunque la Magna Carta englobaba convenciones y costumbres (como era el caso de los llamados "Articles of the Barons"), en ella, eran las libertades y no las costumbres las predominantes. Como escribe Holt $^{23}$, "the Charter was a Charter of liberties in strict contemporary parlance". No ha de extrañar por lo mismo que, según Berger ${ }^{24}$, Coke considerara que la Magna Charta anulaba toda ley que la contrariara, algo asimismo predicable, siempre según el citado autor, del natural law. Una prueba patente de la primacía que Coke siempre reconoció a la Carta Magna la encontramos en el debate sobre la Petition of Rights, en el que declararía que, "saving the King's sovereign power", "la Magna Charta era como un compañero, que no tendrá soberano" ("Magna Carta is such a fellow that he will have no sovereign") ${ }^{25}$, si bien Coke se estaba refiriendo directamente a la idea de "poder soberano", que tal como él la interpretaba, significaba un poder por encima del Derecho, mientras que el poder de prerrogativa era una parte del Derecho. Esta reviviscencia, por así llamarla, llevada a cabo por Coke de la Carta Magna tendría un enorme impacto sobre la teoría constitucional norteamericana. Corwin lo deja muy claro cuando sostiene, que "the eventual role, indeed, of Magna Carta in the history of American constitutional theory is due immediately to its revival at the opening of the seventeenth century, largely by Sir Edward Coke"26.

Ya en el debate desencadenado en sede parlamentaria con ocasión de la prisión decretada por el Rey Carlos I (Rey de Inglaterra, Escocia e Irlanda entre 1625 y 1649) de varios caballeros, a los que había intentado forzarles la concesión de un préstamo, no aduciéndose ninguna causa para su encarcelamiento, rechazando los tribunales en el Five Knights'Case (1627) el habeas corpus requerido para los encarcelados, hecho que se halla en la génesis de la acción parlamentaria que desembocaría en la aprobación de la antes

\footnotetext{
${ }^{23}$ HOLT, J. C.: "The Ancient Constitution in Medieval England", en The Roots of Liberty (Magna Carta, Ancient Constitution, and the Anglo-American Tradition of Rule of Law), edited with an Introduction by Ellis Sandoz, University of Missouri Press, Columbia (Missouri) and London, 1993, pp. 22 y ss.; en concreto, p. 24.

${ }^{24}$ BERGER, Raoul: "Doctor Bonham's Case: Statutory Construction or Constitutional Theory?", op. cit., pp. 535-536.

${ }^{25}$ Apud MacKAY, R. A.: “Coke-Parliamentary Sovereignty...”, op. cit., p. 233.

${ }^{26}$ CORWIN, Edward S.: "The < Higher Law> Background of American Constitutional Law" (I), en Harvard Law Review (Harv. L. Rev.), Vol. XLII, 1928-1929, pp. 149 y ss.; en concreto, p. 175.
} 
mencionada Petition of Rights ${ }^{27}$, Coke, en referencia a la "law of the land", sostendría, que "the law leaves every man a remedy of causeless imprisonment", mencionándose al efecto el capítulo 29 de la Magna Charta y el principio del due process. En sus comentarios a la Carta Magna, Coke conectaría estrechamente la previsión de la misma en su trascendental capítulo 29 a "by lawful judgment of his Peers" (per legale judicium parium suorum) con lo que bien podríamos tildar con términos actuales como unas garantías procedimentales que incluían el juicio por jurados ${ }^{28}$.

Al término del mandato parlamentario iniciado en 1628, Coke se retiró de la vida pública con la finalidad de completar sus Institutes, obra monumental cuya primera parte se publicó ese mismo año, si bien las tres restantes partes no aparecerían hasta 1642-1644, una vez fallecido su autor (en 1634). Ya durante sus etapas como Attorney General y Chief Justice habían aparecido once volúmenes de sus Reports, cuya trascendencia fue desde el primer momento especialmente subrayada ${ }^{29}$, y lo ha seguido siendo después, lo que se comprende fácilmente si se tiene presente el hecho paradójico de que la adhesión al precedente judicial en el Derecho inglés no siempre fue acompañada de la conservación de esos precedentes. Desde 1537, en que se publicó el último Year Book ${ }^{30}$, hasta 1865 no hubo actas oficiales de los casos

\footnotetext{
27 “The Five Knights'Case of 1627 ---escribe Christianson--- worked together (junto a otros factores que ahora no son del caso) to precipitate the debates over the prerogatives of the crown and the liberties of the subject which took place in the parliament of 1628". CHRISTIANSON, Paul: "Ancient Constitutions in the Age of Sir Edward Coke and John Selden”, en The Roots of Liberty, op. cit., pp. 89 y ss.; en concreto, p. 116.

${ }^{28}$ "No Freeman ---establece la Carta--- shall be taken or imprisoned, or be disseised of his Freehold, or Liberties, or free Customs, or be outlawed, or exiled, or any other wise destroyed; nor will We not pass upon him, nor condemn him, but by lawful judgment of his Peers, or by the Law of the Land. We will sell to no man, we will not deny or defer to any man either Justice or Right". El comentario de este Capítulo 29 puede verse en la obra The Selected Writings and Speeches of Sir Edward Coke, edited by Steve SHEPPARD, Liberty Fund, Indianapolis, Indiana, 2003, Vol. Two, pp. 848 y ss.

${ }^{29}$ Ya en 1662, en su History of the Worthies of England, refiriéndose a los Reports de Coke, Fuller escribía, que "they will last to be admired by the judicious posterity whilst fame hath a trumpet left her, and any breath to blow therein". Apud BAKER, J. H.: "Coke's Note-Books and the Sources of his Reports", en The Cambridge Law Journal (Cambridge L. J.), Vol. 30, 1972, pp. 59 y ss.; en concreto, p. 59. Este trabajo puede verse asimismo en la obra Law, Liberty, and Parliament. Selected Essays..., op. cit., pp. 357 y ss. (la cita en p. 357). 30

Los Year Books comenzaron a circular hacia fines del siglo XIII (Baker da como fecha concreta de aparición del primero de ellos la del año 1280) cuando los fundamentos del common law establecidos por los jueces de los reinados de Enrique II y Enrique III estaban siendo modificados a la vista de los estatutos de Eduardo I, hijo de Enrique III y Rey de Inglaterra entre 1272 y 1307 . Hacie el año 1300, estos Reports se habían convertido en una serie cronológica con una cierta reputación entre los juristas, pues como de nuevo señala Baker, los primeros Year Books eran obviamente una criatura de la nueva profesión jurídica.(BAKER, J. H.: An Introduction to English Legal History, Butterworths, $2^{\text {nd }}$ edition, London, 1979, p. 152). Según Vinogradoff, los primeros reports, preocupados por la armonización entre el statute law y el common law, iban a ser de una gran extensión, entrando en todos los detalles judiciales. VINOGRADOFF, Paul: "Constitutional History and the Year Books", en The Law Quarterly Review (L. Q. Rev.), Vol. XXIX, 1918, pp. 273 y ss.; en concreto, p. 274.
} 
judiciales $^{31}$, por lo que este importante trabajo debió correr de cuenta de particulares. Y se admite de modo generalizado, que las clásicas fuentes del viejo common law son los Reports de Edmund Plowden ${ }^{32}$ y de Edward Coke ${ }^{33}$.

\section{Breve aproximación al pensamiento jurídico de Coke}

I. El primer rasgo a subrayar en relación al pensamiento jurídico de Edward Coke es el de su profundo conocimiento del saber clásico; no era esto, por supuesto, algo inhabitual en la época sino, bien al contrario, algo muy común entre los más destacados juristas de los años isabelinos (Isabel I fue Reina de Inglaterra e Irlanda entre 1558 y 1603). No ha de extrañar por ello que los escritos de nuestro Juez estén repletos de citas de escritores latinos: Catón, Juvenal, Salustio, Plinio, Horacio, Séneca, Tácito, Virgilio y Cicerón. Las máximas latinas, un conciso resumen o recapitulación del Derecho, se hallan omnipresentes en sus obras. No debe sorprender por lo mismo, que en un popular libro de máximas jurídicas de nuestra época ${ }^{34}$, de las 1100 máximas recogidas, justamente la mitad se adscriban directamente a Edward Coke.

El estudio de la filosofía jurídica del siglo XVII inglés, comprensiva de cuestiones tales como la naturaleza de este Derecho, sus fuentes, su relación con la moral y la política..., requeriría un análisis de los escritos de autores tales como Thomas Hobbes, Robert Filmer, John Locke, James Harrington y de muchos otros políticos y filósofos jurídicos. Coke iba sin embargo a centrar su preocupación en la identificación de aquellos factores que habían dado al Derecho inglés su naturaleza peculiar. La filosofía jurídica de Coke se iba a centrar de modo específico no ya sobre el Derecho inglés en general sino, más estrictamente aún, sobre una rama de ese Derecho: el English common law, esto es, el Derecho que tradicionalmente se

\footnotetext{
${ }^{31}$ VEEDER, Van Vechten: "The English Reports, 1292-1865” (I), en Harvard Law Review (Harv. L. Rev.), Vol. XV, 1901-1902, pp. 1 y ss.; en concreto, p. 3.

${ }^{32}$ Plowden, que falleció en 1585 , llevó a cabo su recopilación de los casos judiciales entre la década de 1550 y la de 1570. Sus Commentaries se apartaban totalmente del estilo de los Year Books, al esforzarse sobremanera para verificar todos los detalles de los casos, informándose al respecto a través de los abogados y de los propios jueces. Cfr. al efecto, BAKER, J. H.: An Introduction to English Legal History, op. cit., p. 156.

${ }_{33}$ Coke comenzó hacia 1580 a anotar las transacciones jurídicas, perfeccionando su información durante su tiempo de ocio. En 1600 publicó su primer volumen, y poco después, siendo Attorney General, el segundo y tercero. en 1603 apareció el cuarto y dos años más tarde el quinto. Los restantes se publicaron entre los años 1607 y 1616. En su metodología, los Reports de Coke fueron únicos, porque no fueron reports en el sentido estricto del término. El propio Juez advertía en el prólogo de sus libros, que no elaboraba estos informes con vistas a su mera mención ante los tribunales, sino también con propósitos educativos. Cfr. al efecto, VEEDER, Van Vechten: "The English Reports...", op. cit., pp. 9-10.

${ }^{34}$ Latin for Lawyers, $3^{\text {rd }}$ edition, London, 1960. Cit. por BARNES, Thomas G.: "Introduction to Coke's $<$ Commentary on Littleton>", op. cit., p. 22.
} 
aplicaba por los "royal courts of Common Pleas, King's Bench and Exchequer". Coke no intentó desarrollar una teoría del Derecho canónico de la Iglesia, aplicable en los tribunales eclesiásticos ingleses, o de las normas mixtas, canónicas y romanistas, aplicadas en una amplia variedad de tribunales ingleses, pese al conocimiento que de ellas tenía. Es por lo mismo por lo que se considera entre la doctrina ${ }^{35}$, que es a Coke, más que a ninguna otra persona, a quien se debe en Inglaterra la extendida idea de que el Derecho inglés, esto es, the law of the land, tan sólo ha de visualizarse en el English common law, y no, entre otras ramas del Derecho, en "the law of Chancery", "the Ecclesiastical law", "the law of Admiralty", "the law of the Merchants"... etc.

Los muchos escritos de Coke no empecen su primigenia vertiente como hombre de acción, a lo que quizá se pueda anudar su visión del conocimiento del Derecho como una ciencia práctica, que alcanza su fin al formar el juicio de alguien que estudia. Muy posiblemente, en ello también pudo influir su preocupación por los movimientos científicos de la época; está demostrado que la biblioteca de Coke albergaba una gran cantidad de libros de los más relevantes científicos de la era isabelina ${ }^{36}$, aunque su conexión con el movimiento científico no llegó al extremo de Sir Francis Bacon, cuyo rol inspirador de la fundación de la Royal Society es bien conocido, aunque, como escribe Shapiro, "the connection between his leadership in science and his contributions to the legal profession and jurisprudential writings is not frequently noted" ${ }^{, 37}$.

II. Coke va a configurar claramente su visión del Derecho en el Epílogo a la primera parte de sus Institutes (parte que se identifica con el rótulo de "Coke upon Littleton"38) a partir del adagio Ratio est anima legis. Tomándolo como punto de partida, escribe:

\footnotetext{
${ }^{35}$ Entre otros, BERMAN, Harold J.: "The Origins of Historical Jurisprudence...”, op. cit., p. 1679.

${ }^{36}$ En tal sentido, SHAPIRO, Barbara J.: "Law and Science in Seventeenth-Century England", en Stanford Law Review (Stan. L. Rev.), Vol. 21, 1968-1969, pp. 727 y ss.; en concreto, p. 737.

${ }^{37}$ Ibidem, p. 736.

${ }^{38}$ Thomas Littleton, junto a Sir John Fortescue, son considerados las principales figuras del renacimiento del Derecho inglés nativo; Littleton por su tratado sobre el derecho del país (land law), y Fortescue por su exposición de la constitución, uno y otra diferentes del Derecho romano. Para Coke, los Tenures (el tratamiento del Derecho de arrendamientos) de Littleton son "the ornament of the common law, and the most perfect and absolute work that ever was written in any human science". Y en cuanto a la obra de Fortescue, De Laudibus Legum Angliae, escrita entre 1468 y 1471, la encuentra de tal importacia y mérito ("weight and worthiness") que debería estar escrita "in letters of gold". Apud SANDOZ, Ellis: "Fortescue, Coke, and Anglo-American Constitutionalism" (Editor's Introduction), en The Roots of Liberty (Magna Carta, Ancient Constitution, and the Anglo-American Tradition of Rule of Law), op. cit., pp. 1 y ss.; en concreto, p. 5.
} 
"Ratio est anima legis; for then are we said to know the Law, when we apprehend the reason of the Law, that is, when we bring the reason of the Law so to our owne reason, that wee perfectly understand it as our owne, and then and before, we have such an excellent and inseparable propertie and ownership therin (therein), as wee can neither lose it, nor any man take it from us, and will direct us (the learning of the Law is so chained together) in many other Cases. But if by your studie and industrie you make not the reason of the Law your owne, it is not possible for you long to retaine in your memorie. And well doth our author couple arguments and reasons together, Quia argumenta ignota \& obscura ad lucem rationis proferunt \& reddunt splendida: and therefore argumentari \& ratiocinari are many times taken for one"39. (La razón es el alma de la ley; por lo tanto, se dice que conocemos la ley cuando percibimos la razón de la ley, esto es, cuando llevamos la razón de la ley a nuestra propia razón, y la comprendemos perfectamente como la nuestra propia, y entonces, nunca antes, tenemos un excelente e inseparable dominio y propiedad en eso, que ni podemos perderlo, ni ningún hombre quitárnoslo, y que nos dirigirá (nos encadenamos juntos así al conocimiento de la ley) en muchos otros casos. Pero si a través de su estudio y laboriosidad no hace suya la razón de la ley, a Usted no le es posible conservarla en su memoria largo tiempo. Y bien, empareje juntos nuestro autor argumentos y razones. "Porque los argumentos desconocidos y oscuros, a la luz de la razón, se transforman y se presentan resplandecientes", y por eso "argumentar y razonar" son muchas veces tomados como lo mismo).

Añadamos, que Coke finalizará este epílogo con otra nueva máxima latina que se comenta por sí misma: Lex plus laudatur quando ratione probatur.

El Derecho viene a ser así para Coke una ciencia que, con un cierto sentido aristotélico, se presenta como una ciencia práctica, uniendo la razón al conocimiento de aspectos particulares, contenidos no en los libros como un cuerpo de conocimiento, sino en las mentes de los que pueden utilizarla ${ }^{40}$. La definición que de la ley, del Derecho en más amplios términos, hará nuestro Juez, recurriendo de nuevo a una máxima latina: Lex est ratio summa, quae jubet quae sunt utilia et necessaria, et contria prohibet (la ley es la razón culminante, ---la perfección de la razón, si así se prefiere--- que ordena lo que es útil y necesario y que prohíbe lo contrario) ha sido una de las más persistentes y fructíferas definiciones que se ha dado de la ley, pudiendo verse definiciones paralelas en autores tan

\footnotetext{
${ }^{39}$ El "Epilogue" puede verse en The Selected Writings and Speeches of Sir Edward Coke, op. cit., Vol. Two, pp. 742-744. El texto transcrito, en pp. 742-743.

${ }^{40}$ STONER, Jr, James R..: Common Law and Liberal Theory. Coke, Hobbes, and the Origins..., op. cit., p. 18.
} 
diversos como Cicerón, Aristóteles, Henry de Bracton, Jean de Gerson, el gran teólogo francés de la segunda mitad del siglo XIV y primeros lustros del XV), Grocio o Santo Tomás de Aquino. Ello no obsta a que la teoría cokiana de la razón artificial (artificial reason) se nos presente en la época de Coke como un concepto ciertamente revolucionario. Ello es patente si se tiene presente que para nuestro Juez, la ley y el Estado existen tranquilamente sin la necesidad de la presencia del Rey. Esa visión se haría aún más abiertamente revolucionaria tras la publicación de los Reports de Coke. De ahí que se haya podido escribir que "Coke dethroned the monarch only in the realm of law"41, aunque también es cierto, y ello debe inexcusablemente tenerse en cuenta, que el concepto de reason reflejaba una tradición muy arraigada en el Derecho medieval; por lo mismo, se trataba de un concepto que, lejos de ser novedoso, provenía de los siglos precedentes.

Es bastante evidente que, contemplada la ley desde la óptica de John Austin, la concepción de Coke podía visualizarse como ininteligible o inadecuada, por cuanto con ella, como acaba de decirse, el soberano dejaba de tener presencia, mucho menos predominio o primacía, en su definición. Para Coke, la "razonabilidad" de la ley era de algún modo la fuente de su fuerza vinculante, pues a la vista de sus escritos es patente, que antes que mandato y obediencia, "the matching halves of positivist jurisprudence", como las considera Boyer $^{42}$, la "razón artificial" que defiende Coke enfatiza la inteligencia, la responsabilidad y el consenso, y todo ello deja su concepción al margen del poderoso movimiento que se puede apreciar en la doctrina inglesa de vincular la obligación jurídica creada por la ley con algún hecho social, sea el "contrato social", contemplado en Inglaterra por Locke, sea la "habitual obediencia al soberano", a la que aludirá Austin ${ }^{43}$. Cualquier intento de comprender la concepción de Coke desde el punto de vista de la jurisprudencia analítica de los siglos XIX y XX estará llamado al fracaso. Pero nos hallamos ante una cuestión que se halla lejos de estar finiquitada, pues todavía hoy se discute si la ley debe ser un producto de la razón o de la mera voluntad de quien tener poder para dictarla. Pero desde luego, estamos plenamente de acuerdo

\footnotetext{
${ }^{41}$ BOYER, Allen Dillard: “<Understanding, Authority, and Will>: Sir Edward Coke...”, op. cit., p. 92.

${ }^{42}$ Ibidem, pp. 91-92.

${ }^{43}$ LEWIS, John Underwood: "Sir Edward Coke (1552-1634): His Theory of <Artificial Reason> as a Context for Modern Basic Legal Theory”, en Law, Liberty, and Parliament. Selected Essays..., op. cit., pp. 107 y ss.; en concreto, p. 109.
} 
con Lewis, cuando escribe, que "a definition of law in terms of <reasonableness $>$ is better able than a voluntaristic one of giving a realistic account of legal obligation" ${ }^{\text {. }}$.

Esta vinculación entre el Derecho y la razón aparece como una constante del pensamiento y de los escritos de Coke. Más aún, desde el punto de vista que primigeniamente nos interesa, el de la judicial review, tal y como parece sugerirlo alguna mención del Bonham's case, el principio más significativo en la comprensión de la ley por Coke es su insistencia en torno a la ecuación entre el Derecho y la razón. Su persistencia en esta relación bipolar entre ley y razón, concebida siempre como artificial reason, esto es, como razón que existe no por la naturaleza sino por el esfuerzo y la habilidad humanas, se halla omnipresente en su obra. En otro celebérrimo pasaje, que se suele considerar como el favorito del propio Coke, éste comienza señalando, que Nihil quod est contra rationem est licitum (nada contrario a la razón es lícito), fundamentando esta premisa en las siguientes reflexiones:

"For reason is the life of the Law, nay the Common Law it selfe is nothing else but reason, which is to be understood of an artificial perfection of reason, gotten by long studie, observation and experience and not of every mans naturall reason, for Nemo nascitur artifex. This legall reason est summa ratio. And therefore if all the reason that is dispersed into so many several heads were united into one, yet could he not make such a Law as the Law of England is, because by many succession of ages it hath been fined and refined by an infinite number of grave and learned men, and by long experience growne to such a perfection, for the government of this Realme, as the old rule may be justly verified of it, Neminem oportet esse sapientiorem legibus: No man (out of his owne private reason) ought to be wiser than the Law, which is the perfection of reason" ${ }^{\text {"45 }}$. (Pues la razón es la vida del Derecho, más aún, el common law no es en sí mismo sino razón, que tiene que comprenderse como una perfección artificial de la razón, conseguido por el estudio durante mucho tiempo, la observación y la experiencia, y no por la razón natural de los hombres, pues nadie nace maestro (en la ciencia del Derecho) (nemo nascitur artifex). Esta razón jurídica es la razón más elevada (summa ratio). Y por lo tanto, si toda la razón que está dispersa en muy distintas cabezas estuviera unida en una, no podría sin embargo hacer un Derecho tal como el Derecho de Inglaterra es, porque a través de la sucesión de muchas épocas ha sido purificado y refinado por un infinito número de hombres serios y cultos, y a través de una larga

\footnotetext{
${ }^{44}$ Ibidem, p. 120.

${ }^{45}$ Apud The Selected Writings and Speeches of Sir Edward Coke, op. cit., Vol. Two, p. 701. Transcribimos estos textos en su literalidad, lo que, al tratarse de un inglés antiguo, se traduce en la existencia de palabras que no coinciden totalmente con lo que sería su actual versión inglesa.
} 
experiencia se ha desarrollado a tal perfección para el gobierno de este Reino, como para que pueda justamente confirmarse la antigua norma de que Neminen oportet ese sapientiorem legibus: Ningún hombre --fuera de su propia razón personal--- debe ser más sabio, más juicioso, que el Derecho, que es la perfección de la razón).

La concepción que en el párrafo transcrito manifiesta nuestro personaje del common law inglés como encarnación del razonamiento de muchas generaciones de hombres cultos e instruidos, tenía importantes consecuencias filosóficas, pues representaba un concepto diferente de "razón" del que había prevalecido en la filosofía jurídica occidental" ${ }^{46}$ Tanto los filósofos escolásticos de los siglos XII al XV como los filósofos humanistas y neoescolásticos del siglo XVI habían entendido la "razón" como una facultad natural del intelecto humano, una capacidad del ser humano para comprender y formarse un juicio. La razón se contrastaba con la voluntad, que a su vez se visualizaba como una facultad natural para las emociones, que motivaba a una persona a dirigir su mente o su conducta hacia los objetivos deseados. Los filósofos jurídicos escolásticos habían sostenido que la "razón" no sólo facultaba a una persona para distinguir la justicia de la injusticia, sino que también inspiraba qué justicia era preferible. La "razón", se venía a sostener, tiende naturalmente hacia la promoción del bien común, y de aquí que las leyes positivas contrarias a la razón no tuvieran ningún derecho a ser observadas. Los filósofos jurídicos humanistas, tanto católicos como protestantes, no iban a cambiar de modo significativo esta noción del natural law, aunque pondrían especial énfasis en la conveniencia de racionalizar y sistematizar las normas jurídicas en orden a alcanzar unas mejores políticas públicas.

Ante estas posiciones, Coke, por supuesto, no iba a dudar de la existencia de una natural reason y de un natural law, definidos por los filósofos morales y políticos, pero iba a yuxtaponerles un diferente tipo de "razón", que bien podría denominarse historical reason, por cuanto para nuestro Juez, tal "razón" podría identificarse con el desarrollo histórico de la tradición nacional, y de modo más específico, de la tradición del English common law. Y la "razón" en que éste se basaba era el razonamiento de aquellos juristas, abogados y jueces, ingleses que Coke consideraba hombres serios, cultos e instruidos, que a lo largo de los siglos habían venido razonando, argumentando, sobre las más diversas materias jurídicas. En coherencia con ello, Coke iba a defender más que ningún otro pensador, la continuidad

\footnotetext{
${ }^{46}$ Cfr. al respecto, BERMAN, Harold J.: "The Origins of Historical Jurisprudence...”, op. cit., pp. 1690-1691.
} 
ininterrumpida del common law, lo que entrañaba considerar que sus más lejanos precedentes habían sobrevivido. Con todo, esta posición en absoluto era por entero novedosa, pues ya el Chief Justice Sir John Fortescue, al que con frecuencia se vincula con Coke, en su conocida obra De Laudibus Legum Angliae, escrita en los años 1470, había avanzado similar idea. En la mencionada obra se contenían una serie de cuestiones que, como se ha dicho, se adaptaban muy bien con el estereotipo de una "common law mind", por lo que en Fortescue se ha visto una ejemplificación de la tradición jurídica inglesa ${ }^{47}$.

III. La concepción que acabamos de exponer iba a manifestarse con meridiana nitidez en un célebre hecho, conocido como las Prohibitions del Roy, que no sólo revela esa visión cokiana del Derecho como artificial reason, sino que también nos pone de relieve la reivindicación por el Chief Justice de la primacía del Derecho y de su exclusiva aplicación por los jueces. El enfrentamiento entre Coke y el Rey Jacobo I, que está en el origen de este hecho, nos ofrece una extraordinaria riqueza de ideas, pero por fuerza hemos de abordarlo de modo muy esquemático.

El domingo 10 de noviembre de $1608^{48}$ tenía lugar el más sonado de los muchos choques que a lo largo de su vida iba a tener Coke con el Rey. En sus Reports, aparece perfectamente documentado bajo el rótulo ya mencionado, Prohibitions del Roy ${ }^{49}$. El Privy Council se reunía comúnmente la mañana de los domingos en el "Whitehall Palace", con la asistencia de los jueces de common law y de los eclesiásticos, y como es obvio, bajo la presidencia del Rey. Ese día (o quizá el día $13^{50}$ ) se producía un enfrentamiento entre el

\footnotetext{
${ }^{47}$ Christopher W. BROOKS: "The Place of Magna Carta and the Ancient Constitution in Sixteenth-Century English Legal Thought", en The Roots of Liberty, op. cit., pp. 57 y ss.; en concreto, p. 60.

${ }^{48}$ Hay bastantes discrepancias en cuanto a la fecha exacta de la reunión desencadenante del enfrentamiento. El 10 de noviembre es la que aparece en los Reports, pero el dato no es del todo claro. Usher, hace más de un siglo, relativizó un tanto los datos recogidos por Coke en la parte duodécima de sus Reports, con base en que este volumen se había publicado tras la muerte de Lord Coke, y unos meses después de la misma el Rey ordenó la incautación de los documentos de Coke. No fue hasta 1641 cuando el Monarca accedió a la petición de uno de los hijos del Juez para que su heredero, Robert Coke, los restaurara y en su caso los publicara. Y no cabe descartar que alguna modificación pudiera ser introducida. Cfr. al efecto, USHER, Roland G.: "James I and Sir Edward Coke", en The English Historical Review (published by Oxford University Press), Vol. 18, No. 72, October, 1903, pp. 664 y ss.; en particular, pp. 664, 667 y 670.

${ }^{49}$ COKE, Edward: "Prohibitions del Roy" (en Part Twelve of the Reports), en The Selected Writings and Speeches of Sir Edward Coke, op. cit., Vol. One, pp. 478-481.

${ }_{50}$ Bowen, que ha elaborado la que posiblemente sea la mejor biografía de Coke, fija la fecha del domingo 13 de noviembre. A simple vista, queda claro que existe un error de calendario, pues Bowen se refiere no al día 13, sino al domingo día 13. Dado el rigor de la obra de esta autora, parece que la fecha que da es la real. Cfr. al
} 
Arzobispo de Canterbury, Bancroft, y Coke, que degeneraba en un violento choque entre el Rey y el propio Chief Justice.

Ante las pretensiones de Bancroft de ampliar el conocimiento de los tribunales eclesiásticos en ciertos ámbitos, Coke iba a intervenir argumentando que tales tribunales tenían una indiscutida autoridad para conocer en la medida en que los asuntos temporales no se viesen afectados. Pero cuando una cuestión temporal hiciera acto de presencia en el litigio, éste debía transferirse a los common law courts, aún en casos de clara naturaleza eclesiástica. Tras una breve intervención del Rey alguien, que Bowen, biógrafa de Coke, cree que pudo ser el propio Arzobispo Bancroft ${ }^{51}$, planteó la delicada cuestión ("the touchy matter") de las propias facultades del Rey. En sus Reports, Coke no identifica al autor de la siguiente reflexión, expresando tan sólo que el Rey Jacobo I fue informado de que:

"(W)hen the question was made of what matters the Ecclesiastical Judges have Cognizance, either upon the exposition of the Statutes concerning tithes, or any other thing Ecclesiastical, or upon the Statute I Eliz. concerning the high Commission, or in any other case in which there is not express authority in Law, the King himself may decide it in his royal person; and that the Judges are but the delegates of the King, and that the King may take what Causes he shall please to determine, from the determination of the Judges, and may determine them himself" (Cuando se planteó la cuestión de sobre qué asuntos conocen los jueces eclesiásticos, si sobre la interpretación de los estatutos relativos a diezmos, o sobre cualquier otra cosa eclesiástica, o sobre el estatuto de Isabel I relativo a la Comisión superior, o en cualquier otro caso en el que no haya una expresa autoridad en Derecho (se argumentó que) el Rey mismo podía decider por su real persona, y que no siendo los jueces sino delegados del Rey, éste podía quitar de la decisión de los jueces cualquier causa que quisiera decidir, y podía decidirla por sí mismo). A lo que el Arzobispo de Canterbury iba a añadir, "this was clear in Divinity, that such Authority belongs to the King by the Word of God in the Scripture" 52 (esto era claro en la Teología, que tal autoridad pertenece al Rey por la palabra de Dios en las Escrituras).

A ello Coke iba a responder de modo rotundo: "That the King in his own person cannot adjudge any case, either criminal ---as treason, felony, \& c., or betwixt party and party,

respecto, BOWEN, Catherine Drinker: The Lion and the Throne (The Life and Times of Sir Edward Coke. 1552-1634), Hamish Hamilton, London, 1957, pp. 260-261.

${ }^{51}$ BOWEN, Catherine Drinker: The Lion and the Throne, op. cit., p. 261.

${ }^{52}$ Apud The Selected Writings and Speeches of Sir Edward Coke, op. cit., Vol. One, p. 479. 
concerning his inheritance. chattels, or goods, but this ought to be determined and adjudged in some court of justice, according to the Law and Custom of England"53. (Que el Rey por su propia persona no puede juzgar ningún caso, ni criminal, como traición o delito grave..., ni entre parte y parte, acerca de su herencia, bienes o mercancías, sino que esto debe decidirse y sentenciarse en algún tribunal de justicia, según el Derecho y la costumbre de Inglaterra). Coke añadía sentirse enormemente asombrado ("greatly marvelled") de que el Arzobispo se atreviera a informar al Rey de que tal autoridad y poder absolutos pertenecieran al Monarca por la palabra de Dios ${ }^{54}$. El Soberano, añadió Coke dirigiéndose al Rey, puede ocupar un lugar en la Star Chamber (Cámara Estrellada), "and this appears in our books". Pero sólo para consultar con los jueces, no para juzgar ("not in iudicio"). "And it appears by Act of Parliament ---concluiría nuestro Chief Justice--- that neither by the Great Seal nor by the Little Seal, justice shall be delayed; ergo, the King cannot take any cause out of any courts and give judgment upon it himself..." ${ }^{, 55}$. (Y aparece por ley del Parlamento, que ni por el sello real, ni por cualquier otro sello puede la justicia ser retrasada; por consiguiente, el Rey no puede apropiarse de ninguna causa al margen de cualquier tribunal y dictar sentencia sobre ella por sí mismo).

Una vez que Coke expuso diferentes precedentes que apoyaban su argumentación, el Rey Jaime respondió que él pensaba que el Derecho se hallaba fundado en la razón y que tanto él como otros tenían razón, lo mismo que los jueces, con lo que, de modo implícito, estaba reivindicando su potestad de, llegado el caso, decidir ciertos casos litigiosos. Frente a ello, Coke, según refleja en sus propios Reports, iba a replicar de modo brillante y persuasivo:

"(T)hat it was, that God has endowed his Majesty with excellent Science, and great endowments of nature; but his Majesty was not learned in the Lawes of his Realm of England, and causes which concern the life, or inheritance, or goods, or fortunes of his subjects; they are not to be decided by naturall reason but by the artificiall reason and judgment of Law, which Law is an act which

\footnotetext{
${ }^{53}$ Apud BOWEN, Catherine Drinker: The Lion and the Throne..., op. cit., pp. 261-262.

${ }^{54}$ Cabe recordar que la genérica noción de que curia domini debet facere iudicia et non dominus, se hallaba sólidamente arraigada en la Edad Media encontrando expresión, como recuerda Yale, en ciertos límites jurídicos sobre lo que el Rey podía o no podía conceder a través de la delegación o transmisión de facultades jurisdiccionales. YALE, D. E. C.: "Iudex in propria causa: An Historical Excursus", en Cambridge Law Journal (Cambridge L. J.), Vol. 33, 1974, pp. 80 y ss.; en concreto, p. 86.

${ }^{55}$ Apud The Selected Writings and Speeches of Sir Edward Coke, op. cit., Vol. One, p. 480.
} 
requires long study and experience, before that a man can attain to the cognizance of it; and that the Law was the Golden metwand and measure to try the Causes of the Subjects; and which protected his Majesty in safety and peace" ${ }^{, 56}$. (Que era verdad que Dios había dotado a Su Majestad con una excelente ciencia y grandes dones de la naturaleza, pero Su Majestad no estaba instruido en las leyes de su Reino de Inglaterra, y las causas que conciernen a la vida, a la herencia, a los bienes o fortunas de sus súbditos, no tienen que decidirse por la razón natural sino por la razón artificial y la decisión del Derecho; que el Derecho es una obra que requiere largo estudio y experiencia de que un hombre pueda alcanzar su conocimiento, y que el Derecho era la vara aúrea y la medida para juzgar las causas de los súbditos, y que protegía a Su Majestad en seguridad y paz).

Ante tal disertación, según recoge Coke en sus Reports, el Rey se mostró muy ofendido y dijo, que era traición afirmar ("was treason to affirm") que él debía estar sometido a la ley, al Derecho, a lo que Edward Coke reconoce haber replicado lo que Henry de Bracton ---el primer gran jurista inglés, que vivió en el siglo XIII, siendo Juez del King 's Bench durante el reinado de Enrique III (Rey de Inglaterra entre 1216 y 1272) y autor del relevante tratado De Legibus et Consuetudinibus Angliae, escrito entre 1250 y 1256, aunque no se publicó hasta 1569 , obra en la que se puso en contacto por primera vez el naciente common law con el Derecho romano--- ya había sostenido: Quod Rex non debet esse sub homine, sed sub Deo et lege ${ }^{57}$, o lo que es igual, que el Rey no debe hallarse sujeto a ningún hombre, sino tan sólo a Dios y al Derecho ${ }^{58}$. Para tener una visión más completa, quizá convenga recordar, que antes de llegar al trono de Inglaterra en 1603, Jacobo había reinado como Jacobo VI en Escocia, un reino cuyo Derecho se basaba en el Derecho romano. De ahí que el Rey no estuviese familiarizado con el common law o con sus racionalizaciones. Su concepto del Derecho provenía de los jueces reales del Antiguo Testamento y del Derecho romano escocés. Para él, el Derecho no era sino una expresión de la voluntad regia; por lo tanto, el Monarca

\footnotetext{
${ }^{56}$ Apud The Selected Writings and Speeches of Sir Edward Coke, op. cit., Vol. One, p. 481.

${ }^{57}$ El célebre pasaje contenido en el tratado de Bracton dice lo siguiente: "The King himself ought not to be subject to man, but subject to God and to the law, for the law makes the King. Let the King then attribute to the law what the attributes to him, namely, dominion and power, for there is no King where the will and not the law has dominion". Como escribiera Corwin, en estas palabras tenemos contenida la característica idea medieval de la autoridad, concebida como derivación del Derecho y, por lo tanto, limitada por el mismo. CORWIN, Edward S.: "The $<$ Higher Law> Background of American Constitutional Law" (I), op. cit., pp. 172-173.

La consideración antes referida de Bracton entrañaba que lex facit regem, términos que el propio Coke aprobó. Con ellos quedaba planteada la cuestión de si para Edward Coke el Rey se hallaba sujeto asimismo al Derecho estatutario, de aprobación parlamentaria. A juicio de Mullett, para Coke, aunque no lo dijera de modo específico, el Parlamento era supremo sobre aquellos atributos regios que no estaban única e inseparablemente ligados a la persona del Monarca. MULLETT, Charles F.: "Coke and the American Revolution”, op. cit., p. 466.
} 
era la fuente del Derecho y su intérprete supremo, del que los jueces inferiores extraían su autoridad.

En el fondo de todo ello hacía acto de presencia la profunda diferenciación existente en la época entre los diversos civil law systems de la Europa continental, pero también de Escocia, y el English legal system, diferencias de las que iban a derivar asimismo importantes consecuencias políticas. John Wycliffe, en su De Officio Regis (1379), y posteriormente, y aún en mayor medida, Sir John Fortescue, al que ya nos hemos referido, considerado un relevante precursor del historicismo ${ }^{59}$, doctrina que había de convertirse en dominante en el pensamiento jurídico inglés del siglo XVII, al remontarse (en la ya mencionada De Laudibus Legum Angliae) en su búsqueda de los orígenes del Derecho inglés hasta costumbres inmemoriales, que incluso se habían de situar cronológicamente en tiempos anteriores al dominio romano, se iban a hacer eco de tales divergencias. Fortescue iba a distinguir entre lo que denominaba el dominium politicum et regale característico de Inglaterra, y el continental (particularmente francés) dominium regale ${ }^{60}$. Esta divergencia se traducía en que mientras en Inglaterra el Rey carecía de poder para cambiar la ley sin lograr el asentimiento del conjunto del Reino representado en el Parlamento, la voluntad del Monarca francés era absoluta, quedando habilitada por la famosa máxima de Justiniano, Quod principi placuit legis habet vigorem (Lo que le agrada al príncipe tiene fuerza de ley). Innecesario es decir, que bajo ese sistema de civil law los Reyes podían convertirse fácilmente en tiranos, mientras que el English common law establecía una barrera frente a esa degeneración, encaminada a mantener la libertad del súbdito.

IV. Un sector de la doctrina ha considerado ${ }^{61}$, que la más importante contribución de Coke a la filosofía jurídica inglesa fue su identificación del fundamental law de Inglaterra con su constitución no escrita, esto es, con el propio common law. Para nuestro Juez, el common law se había encontrado, no se había hecho. Eran el Parlamento, los jueces y "the King in Council" quienes lo habían encontrado, lo que ya nos muestra que Coke iba a adscribir el common law a una variedad de fuentes. Por supuesto, como se acaba de decir, el Derecho positivo también se integraba en el common law; Coke nunca dudó de la fuerza vinculante de

\footnotetext{
${ }^{59}$ BERMAN, Harold J.: "The Origins of Historical Jurisprudence...”, op. cit., p. 1658.

${ }^{60}$ HELGERSON, Richard: "Writing the Law", en Law, Liberty, and Parliament. Selected Essays..., op. cit., pp. 26 y ss.; en concreto, pp. 30-31

${ }^{61}$ BERMAN, Harold J.: “The Origins of Historical Jurisprudence...”, op. cit., pp. 1681 y 1693.
} 
la legislación, pero él visualizó el Derecho estatutario, emanado del Parlamento, dentro del contexto histórico de los precedentes de los tribunales ingleses de common law, lo que podía conducir a pensar en la primacía de ese fundamental law sobre el Derecho positivo.

Entre los ingleses de la época, aún existiendo la idea de un fundamental law, no se hallaba del todo claro qué tipo de reglas o normas podían considerarse fundamentales, o dicho de otro modo, cuál era el contenido de ese fundamental law. Para algunos, el fundamental law estaba encerrado en el common law y en esas instituciones del common law tales como el trial by jury (juicio por jurados), que se creía que encontraban sus raíces en un remoto, pero puramente inglés, pasado sajón, anterior a la conquista normanda ${ }^{62}$.

En el "Preface" de la cuarta parte de sus Reports, Coke hace algunas consideraciones que no parecen sugerir que alguna forma de Derecho fuera inmutable, limitándose a poner de relieve que, en ocasiones, podía ser inconveniente o incluso peligroso innovar ese Derecho ${ }^{63}$. Roscoe Pound, el gran Decano de Harvard, pudo observar al respecto ${ }^{64}$, que Coke siempre fue consciente de que aunque el Derecho ha de ser estable y firme, no debe permanecer completamente inmóvil. En el siglo XVII, quizá el único modo de que esta paradoja de la estabilidad y la flexibilidad plástica del Derecho pudiera resolverse era a través de una consciente reinterpretación, tanto por los jueces como por los abogados, de los valiosos textos jurídicos del pasado. Coke se alineó en esta dirección y, en coherencia con ella, trató de adaptar el common law medieval, contemplado como tal primariamente a través de la Magna Charta, a las necesidades de su propia sociedad.

No cabe duda de que la Carta Magna, que Henry de Bracton, en su De Legibus et Consuetudinibus Angliae, calificó de constitutio libertatis, una expresión que, como dice Corwin $^{65}$, a sabiendas o no, atribuye a la Carta la consolidación de todas las libertades concretas en una libertad ("one liberty"), se contempló como la fuente de todas las fundamental laws del reino. Coke se ocupó de ella y de aquellas leyes (statutes) que, a su juicio, más afectaban a los derechos e intereses de Inglaterra, comentando cada una de las secciones de esos textos. Innecesario es decir que el más significativo comentario está

\footnotetext{
${ }^{62}$ Cfr. al efecto, STIMSON, Shannon C.: The American Revolution In The Law (Anglo-American Jurisprudence Before John Marshall), The Macmillan Press, London, 1990, p. 15.

${ }^{63}$ El "Preface" puede verse en The Selected Writings and Speeches of Sir Edward Coke, op. cit., Vol. One, p. 95.

${ }^{64}$ POUND, Roscoe: Law Finding Through Experience and Reason, 1960, p. 23. Cit por George P. SMITH, II': "Dr. Bonham's Case and Modern Significance...", op. cit., p. 300.

${ }^{65}$ CORWIN, Edward S.: "The < Higher Law> Background of American Constitutional Law" (I), op. cit., p. 177. En algún otro lugar de su obra, Bracton habla simplemente de Constitutio en referencia a la Carta Magna.
} 
dedicado a la Carta Magna de 1215, de la que Coke dirá que no era grande en cantidad, pues con posterioridad a ella se habían aprobado varias voluminosas Charters, "but in respect of the great importance, and weightinesse of the matter"66. Pocas líneas después, Coke establecería un simil que siempre le resultó muy querido, al comparar la Carta Magna con Alejandro Magno, llamado así no en atención al tamaño de su cuerpo, pues era un hombre de baja estatura, "but in respect of the greatnesse of his heroicall spirit, of whom it might be truly said, Mens tamen in parvo corpore magna fuit ${ }^{, 67}$. (Sin embargo, grande fue la mente en el pequeño cuerpo). Coke fue, desde luego, la figura clave en la reviviscencia de la Magna Charta, y el rol desempeñado en la historia de la teoría constitucional americana por la Carta Magna, particularísimamente por su capítulo 29, se debe en gran parte a Coke.

Los escritos de Coke fueron una de las mayores colecciones de reglas del common law y posibilitaron que éste pudiera adquirir la posición relevante que vino a ocupar en el siglo XVII como resultado de los conflictos constitucionales de la época. Con toda justicia, los escritores de folletos del siglo XVII vieron a Coke como "the great oracle" de la tradición del common $\operatorname{law}^{68}$, a causa de que él había justamente realizado el decisivo servicio de filtrar esta tradición para su conocimiento y utilización en ese siglo, y también como es obvio en los sucesivos. Nuestro Chief Justice no sólo ensalzó el common law, al igual ciertamente que otros escritores del siglo XVII, sino que, en ocasiones, como antes se dijo, se refirió a él como un fundamental law, y otras veces lo identificó con el Derecho natural ("the law of nature"), lo que resultaría meridianamente claro en el importante Calvin's Case, también conocido como the Case of the Postnati (1608) ${ }^{69}$. El nuevo planteamiento del common law llevado a cabo por Coke facilitó la adaptación de las reglas de common law medievales a las necesidades del Estado moderno, y a la par, ayudó a la venidera supremacía parlamentaria. Bacon llegaría a admitir, que si no hubiera sido por los Reports de Coke, "the Law by this

\footnotetext{
66 "Proeme to the second Part of the Institutes of the Lawes of England", en The Selected Writings and Speeches of Sir Edward Coke. op. cit., Vol. Two, pp. 746 y ss.; la mención transcrita en p. 746.

${ }^{67}$ Ibidem, p. 747.

${ }^{68}$ JONES, David Martin: "Sir Edward Coke and the Interpretation of Lawful Allegiance in Seventeenth-Century England", en Law, Liberty, and Parliament. Selected Essays..., op. cit., pp. 86 y ss.; en concreto, p. 87.

${ }^{69}$ El Calvin's Case puede verse en The Selected Writings and Speeches of Sir Edward Coke, op. cit., Vol. One, pp. 166 y ss. Sobre este caso, que la autora a la que nos referimos de inmediato considera que fue central en el debate sobre el poder del Parlamento en los dominios ingleses, cfr. BLACK, Barbara A.: "The Constitution of Empire: The Case for the Colonists", en University of Pennsylvania Law Review (U. Pa. L. Rev.), Vol. 124, 1975-1976, pp. 1157 y ss.; en particular, pp. 1175-1184.
} 
time had been like a ship without ballast" (el Derecho por esa época hubiera sido como un barco sin lastre $)^{70}$.

\section{El Case of the College of Physicians o Bonham's Case (1610). Los hechos del caso.}

I. No cabe la menor duda de que el Case of the College of Physicians, más comúnmente conocido como el Bonham's Case, es el más famoso caso resuelto por el Chief Justice, e incluso el más conocido de los Reports de Coke ${ }^{71}$. Del caso existen dos informes, uno como es obvio del propio Coke, que presidió el juicio como Chief Justice del Common Pleas; el otro de Brownlow, quien como protonotario del tribunal se halló presente en las últimas etapas del caso.

El litigio que se formalizó ante el tribunal presidido por Coke lo fue a través de una acción "for false imprisonment" (por prisión ilegal) que presentó Thomas Bonham contra Henry Atkins, George Turner, Thomas Moundford y John Argent, doctores en medicina, y John Taylor y William Bowden, pequeños terratenientes, todos ellos miembros principales del "Royal College of Physicians" (Real Colegio de Médicos) de Londres.

El tema de la litis se hallaba lejos de ser trascendente. Innecesario es decir que su enorme fama deriva del pasaje de la sentencia en el que tradicionalmente se ha entendido, por lo menos por amplios sectores de la doctrina científica, que Coke estableció la teoría de que el Derecho estatutario tiene que respetar unos principios superiores de Derecho y justicia, o lo que es igual, un fundamental law, por cuanto éste tiene un carácter vinculante frente a todos los poderes constituidos, incluido el Parlamento, y no haciéndolo así puede ser considerado nulo por los tribunales de common law.

La doctrina moderna ha debatido intensamente el exacto significado del más célebre y reiterado pasaje de la sentencia, al que nos referiremos más adelante, si bien, como ya se ha dicho, es patente que para los hombres de la era de formación de la teoría constitucional americana el significado era muy claro. Como escribe Schwartz ${ }^{72}$, Coke estaba afirmando, como un principio de Derecho positivo, que existía un fundamental law que limitaba a la

\footnotetext{
${ }^{70}$ Apud MULLETT, Charles F.: "Coke and the American Revolution”, op. cit., p. 466.

${ }^{71}$ El caso se incluye dentro de la "Part Eight of the Reports". Puede verse en The Selected Writings and Speeches of Sir Edward Coke, op. cit., Vol. One, pp. 264 y ss.

72 SCHWARTZ, Bernard: A History of the Supreme Court, Oxford University Press, New York/Oxford, 1993, p. 5.
} 
Corona y al Parlamento indistintamente. ¿No había concluido Lord Coke que cuando una ley del Parlamento era contraria a ese fundamental law debía ser juzgada nula? ¿No significaba eso que cuando el Gobierno británico actuaba respecto de sus colonias de un modo contrario al common right and reason sus decretos carecían de fuerza jurídica?

II. Los hechos del caso creemos que son bien conocidos, por lo que nos detendremos en ellos de modo esquemático. Sus protagonistas serían Thomas Bonham y el Royal College of Physicians. El Colegio de Médicos había sido fundado en 1518 bajo la Cancillería del Cardenal Wolsey. Una ley del Parlamento confirmó su charter, que había sido aprobada durante el reinado de Enrique VIII (Rey de Inglaterra entre 1509 y 1547). De conformidad con tal ley, el College obtuvo el derecho a actuar como un tribunal en orden a juzgar a todos los que practicaban la medicina en Londres, lo que se traducía en la admisión como miembros de quienes considerara académicamente cualificados, en la concesión de licencias a quienes, sin una cualificación académica, hubieren demostrado su experiencia práctica, y en el castigo de quienes ejerciesen la medicina deficientemente o sin su autorización. Una ley del primer Parlamento de la Reina María también permitió a los dignatarios del Colegio decidir la prisión de los infractores y mantenerlos encarcelados a su voluntad. De esta forma, como dice $\mathrm{Cook}^{73}$, la autoridad jurídica del Colegio se alzaba frente a la pretensión del common law de que para practicar la medicina uno no necesitaba más que el consentimiento del paciente. Y todo ello, al margen ya de que las competencias del Colegio para autorizar la práctica de la medicina se superponían con las de los obispos, de otorgar licencias a los médicos y cirujanos ("surgeons"), y con la capacidad de las Universidades de emitir licencias para la práctica asimismo de la medicina y cirugía.

Thomas Bonham, según los archivos de la Universidad de Cambridge, se había matriculado como becario ("sizar") en el "St. John's College" durante el período de la Pascua de 1581. Con toda probabilidad, debió cursar los siete años requeridos en Cambridge para la obtención del grado de la licenciatura. Incluso es probable que accediera a un título de “medical doctorate" en la propia Universidad a mediados de la década de los noventa.

\footnotetext{
${ }^{73}$ COOK, Harold J.: "Against Common Right and Reason: The College of Physicians v. Dr. Thomas Bonham", en Law, Liberty, and Parliament. Selected Essays..., op. cit., pp. 127 y ss.; en concreto, p. 130.
} 
Asociado a la "Barber-Surgeon's Company", y con la intención de obtener el derecho de administrar "internal remedies", esto es, ayuda médica, Bonham formalizó una petición ante el Parlamento a principios del año 1605, a lo que el Colegio se opuso. Así las cosas, Bonham debió pensar que su mejor estrategia era la de asociarse al Colegio, a cuyo efecto, el 6 de diciembre de 1605, se presentó por propia iniciativa ante los "censores", esto es, los miembros del comitia censorum, del Real Colegio para el pertinente examen, necesario como antes se dijo para acceder a la condición de miembro del College. Las respuestas no plenamente satisfactorias a las preguntas que se le formularon frustró su propósito. El 14 de abril del siguiente año Bonham retornó al examen, calificándosele esta vez sus respuestas como "no pertinentes". Además, de resultas de haber estado practicando la medicina en Londres durante varios años sin ser miembro del Colegio ni disponer de su autorización, se le impuso por los censores una multa de 5 libras (una cantidad respetable para la época), a ser pagada en la inmediata reunión posterior del comitia censorum, al margen ya de ser amenazado por los censores con la prisión si no cumplía la obligación contraída. Bonham no retornó para un nuevo examen y continuó practicando la medicina. El 3 de octubre de 1606, los censores anotaron en las actas del Colegio, que el Dr. Bonham continuaba ejerciendo prácticas contrarias a lo estipulado en los estatutos y leyes que regían el Royal College y tras varias citaciones sin lograr que se presentara, Bonham fue arrestado y condenado a una multa de 10 libras.

El 7 de noviembre de 1606, Bonham se presentó ante el comité de censores (comitia censorum) acompañado de un Abogado. El presidente del College, Henry Atkins, le recordó sus reiteradas desobediencias y le preguntó si acudía para repararlas o para examinarse de nuevo. Bonham adujo que practicaba la medicina y la iba a seguir practicando sin requerir la autorización del Colegio y sin obedecer a su presidente, pues ellos careecían de competencia sobre quienes se habían graduado en las Universidades, cuestión sobre la que el Abogado que le acompañaba incidió, interpretando en ese sentido diversas cláusulas de las normas que regían el College. Pero como a simple vista la ley estaba a favor del Colegio, su presidente y los censores decidieron enviar a Bonham a prisión, situación que había de mantenerse a la voluntad de aquéllos al estimar que el médico había incurrido en desacato ("for contempt") . Sin embargo, en una semana, el abogado de Bonham había formalizado un writ of habeas corpus ante la Court of Common Pleas, que procedía liberarle el 13 de noviembre. 
Diversas circunstancias en las que no podemos entrar ahora contribuyeron a que se desatara una cierta preocupación entre los dignatarios del Colegio ${ }^{74}$. Ante ello, los miembros dirigentes del College iban a mantener una reunión en la casa del Lord Chancellor, Ellesmere, a la que iban a asistir seis relevantes jueces, dos de ellos de la Court of King's Bench y otros de la Court of Common Pleas. Significativamente, Coke, presidente de la última, no iba a ser invitado. Sus discrepancias con Ellesmere eran harto conocidas. En lo básico, los jueces presentes se pronunciaron sobre cuestiones generales que podían incidir sobre el asunto de Thomas Bonham, inclinándose en favor de las tesis del College $e^{75}$, lo que decidió a sus dirigentes a proceder judicialmente contra nuestro médico ante los common law courts. Finalmente, a principios de 1608, el colegio formalizó la demanda contra Bonham ante el King 's Bench, por doce meses de práctica ilícita de la medicina, reclamando 5 libras de multa por mes, lo que totalizaba 60 libras, una elevadísima cantidad. De modo bien significativo, la demanda era sostenida no por el abogado del Colegio sino por el propio Attorney General, Hobart. El 3 de febrero de 1609, el King 's Bench hacía público su veredicto, siendo Bonham declarado culpable de ejercer la medicina ilícitamente y multado con 60 libras; al negarse a pagarlas, Bonham fue encarcelado por decisión del propio College.

Gray ha explicitado haber encontrado unas evidencias no publicadas de este proceso, aunque también admite haber encontrado unas actas del mismo en un manuscrito del British Museum con una considerable extensión ${ }^{76}$. El propio autor se hace eco de cómo el abogado de Bonham, Damport, en ese proceso sostuvo que las leyes debían interpretarse de acuerdo con la razón ("by reason") y que no era razonable ("it is unreasonable") incluir en los textos legales en cuestión a los doctores por una Universidad.

III. Poco antes de que ser condenado por el King's Bench, Bonham pasaba al contraataque, y a tal efecto retornaba ante el Tribunal del Chief Justice Coke (la Court of Common Pleas), que ya antes le había concedido el habeas corpus, presentando en el otoño de 1608 una demanda contra el Colegio en la que le exigía una indemnización de 100 libras por abuso contra su persona y encarcelamiento injusto o ilegal ("wrongful imprisonment"),

\footnotetext{
${ }^{74}$ Cfr. al respecto, COOK, Harold J.: “Against Common Right and Reason...”, op. cit., pp. 135-136.

${ }^{75}$ Fruto de la reunión sería la aprobación del documento "Opinions of Lord Chancellor and Judges on Question re Charter of College of Physicians" (1607).

${ }^{76}$ GRAY, Charles M.: "Bonham's Case Reviewed", en Proceedings of the American Philosophical Society (Proc. Amer. Phil. Soc.), Vol. 116, No. 1, February 15, 1972, pp. 35 y ss.; en concreto, p. 41.
} 
aduciendo, que el College "with force of arms.... took and imprisoned" "against the law and custom of this kingdom of England".

Los diversos alegatos presentados ante el Tribunal no dejan de ofrecer interés. Los demandados iban a exponer que las cartas patente que provenían de Enrique VIII les habían constituido en sociedad como el Royal College of Physicians, con facultades para multar a quienes practicaran la medicina en Londres, y en una pequeña área circundante, sin haber sido admitidos por ellos, además ya de dotarles de poderes generales para regir a todos los médicos de Londres y del distrito, imponiéndoles, llegado el caso, sanciones de multa y prisión, yendo en la totalidad de los casos la mitad de la multa al Rey y quedando en manos del Colegio la otra mitad. Esta patente fue confirmada por una ley del Parlamento de 1540, en la que se adicionaba un mandato general dirigido a todos los carceleros para mantener a las personas que les confiaran el Presidente y el Colegio sin ponerlas en libertad bajo fianza. Con la Ley de 1540 se pretendía que "none shall practice here but those which are most learned and expert, more tan ordinary", añadiéndose que ello respondía a la necesidad sentida por el Rey de tener un especial cuidado por la salud del pueblo de Londres, ya que "(it) is the heart of the kingdom".

Frente a esto, el abogado de Bonham iba a replicar mediante una argumentación que atendía a la intención de las referidas normas jurídicas. Las leyes del College y sus charters pretendían impedir una mala práctica en el ejercicio de la medicina, como asimismo que se ejerciese por impostores. Siendo un licenciado en medicina por la Universidad de Cambridge, Thomas Bonham era uno de los "grave and learned men" a quienes la ley trataba de estimular. El hecho de que poseyera un grado universitario debía por lo tanto eximirle de la jurisdicción del Colegio. El abogado de Bonham concluía, que la ley "doth not inhibe a doctor to practice, but (only) punisheth him for ill using, exercising, and making (of physic) — it could punish an M. D. for malpractice but not for illicit practice" ${ }^{97}$. En definitiva, según el letrado, el Colegio podía decretar la prisión de un impostor por razón de su deficiente ejercicio de la medicina, pero no lo podía hacer respecto a un doctor culto e instruido como era el caso de su cliente.

Recuerda Plucknett ${ }^{78}$, que una prolongada discusión se produjo en el tribunal sobre la cuestión de si los graduados de las Universidades se hallaban bajo la jurisdicción del Royal College, pues como Sergeant Doddridge sostuvo, "las leyes de este Reino han tenido siempre

\footnotetext{
${ }^{77}$ Apud COOK, Harold J.: "Against Common Right and Reason...", op. cit., p. 138.

${ }^{78}$ PLUCKNETT, Theodore F. T.: "Bonham's Case and Judicial Review”, op. cit., pp. 32-33.
} 
un gran respeto por los graduados de las Universidades, y esto no es sin motivo". De hecho, éste sería el argumento nuclear del defensor de Bonham, aunque, como después veremos, el argumento no fue finalmente tomado en consideración por el Tribunal.

Los cinco Jueces integrantes de la Court of Common Pleas (Foster, Walmesley, Daniel y Warburton, además obviamente del Chief Justice Coke) expresaron sus opinions, como por lo demás era habitual en Inglaterra, seriatim, esto es, uno tras otro individualmente. Las diversas actas del caso difieren algo, variando en su grado de complitud; de ahí que se haya constatado ${ }^{79}$ la existencia de alguna inseguridad acerca exactamente de cómo fue la votación, aunque es evidente que Bonham venció en este litigio, aunque por un ajustado margen de 3-2, y también es claro que no se le dio la razón con apoyo en los fundamentos que su abogado había esgrimido ante el Tribunal. Mientras Coke y el Justice Daniel se pronunciaban en contra del Colegio en todas las cuestiones planteadas, los Justices Foster y Walmesley hacían justamente lo contrario, decantándose en contra del demandante en todos los puntos. Warburton mantuvo una especie de voto oscilante ("a swing vote"). Este Juez había sido uno de los presentes en la reunión que en 1607 había tenido lugar en la casa del Lord Chancellor, a la que aludimos con anterioridad, y en la que, por unanimidad, los asistentes se habían pronunciado en favor de la posición del College. Sin embargo, ahora Warburton se posicionaba en contra de mantener a Bonham en prisión, conformando con Coke y Daniel la posición mayoritaria.

\section{Los argumentos en que se sustenta la sentencia.}

I. El Chief Justice, en un momento dado de su sentencia, iba a mencionar a Galeno, el célebre médico griego nacido en Pérgamo el año 129 de nuestra era, pues no en vano su obra, extraída en gran parte de las teorías de Hipócrates y Aristóteles, se mantuvo como principal fuente del saber médico hasta mediados del siglo XVII. En modo alguno era inadecuada esta mención si se recuerda una de sus máximas: Ubi philosophia definit, ibi medicine incipit (Donde la filosofía termina, allí comienza la medicina), lo que era tanto como reconocer que no había nada seguro en las cuestiones médicas. La consideración no era en absoluto impertinente, pues lo que Coke estaba intentando poner de relieve con su mención

\footnotetext{
${ }^{79}$ STONER, Jr., James R.: Common Law and Liberal Theory..., op. cit., p. 49.
} 
era, que la autoridad que por la charter se había concedido al College no le otorgaba el deber y la capacidad para decidir lo apropiado y lo inapropiado del ejercicio de la medicina.

Esa autoridad se plasmaba legalmente en dos facultades separadas que se contenían en dos cláusulas diferenciadas, concerniendo la primera de ellas a la práctica ilícita de la medicina (illicite practice), en relación a la cual era indiferente que el ejercicio médico fuera bueno o malo, y la segunda (única que autorizaba la prisión del ejerciente de la medicina), a la práctica inadecuada, mala, deficiente (malpractice) (los jueces habían traducido en 1607 la expresión latina "non bene exequend faciend et utend illa" por la inglesa "not well doing, using, or practicing physic"). Coke, con una lógica indiscutible, iba a considerar que las dos cláusulas se referían a cuestiones separadas, en vez de entender la segunda como una suerte de autorización para castigar el comportamiento contemplado por la primera. Y aquí reside la médula vertebral de la sentencia.

Nuestro Chief Justice iba a inclinar su decisión a favor de Bonham con base en dos razonamientos, cada uno de los cuales, como bien se ha dicho ${ }^{80}$, era suficiente por sí solo: 1) Los censores no tenían facultad para encarcelar al demandante por cualquiera de las causas mencionadas ante el Tribunal. 2) Admitiendo que los censores tuvieran por ley esa facultad, ellos no habían perseguido judicialmente en forma adecuada su autoridad. En otras palabras, o la ley del Parlamento no otorgaba a los censores la facultad de encarcelar a Bonham o, si se la daba, los censores no habían seguido sus disposiciones en sus actuaciones contra él.

Para resolver la primera y capital cuestión, Coke iba a aducir cinco argumentos, el cuarto de los cuales es el más célebre pasaje de la sentencia, aquel en el que tradicionalmente se ha visto un reconocimiento de la autoridad de revisión judicial de las leyes (judicial review). Tras ello, el Chief Justice iba a compendiar sus argumentos en dos máximas, para terminar planteando, y refutando, las tres posibles objeciones frente a su argumentación. La segunda cuestión es resuelta de modo más expeditivo, ofreciendo seis argumentos y suscitando, y rechazando, una posible objeción.

II. El abogado de Bonham, como antes dijimos, centró su argumentación en que como licenciado universitario que era su cliente debía quedar al margen de la aplicación de la

\footnotetext{
${ }^{80}$ STONER, Jr., James R.: Common Law and Liberal Theory..., op. cit., p. 50.
} 
ley que nos ocupa. No lo iba a entender así el tribunal, que como era lógico abordaba esta cuestión con carácter previo.

La ley en consideración era lo que se denominaba un estatuto negativo ("a negative statute"). Los términos de la patente eran claros cuando determinaban, que nadie practicaría la medicina en la ciudad de Londres y en su distrito si no fuera admitido por las cartas del presidente y del College, selladas con el sello común. Recuerda Thorne ${ }^{81}$, que por aquel entonces era un principio general de la interpretación jurídica que los estatutos (esto es, las leyes aprobadas por el Parlamento) expresados en términos negativos reemplazaban y anulaban ("superseded and defeated") al common law. Ahora bien, un estatuto negativo no podía ser extendido para incluir casos no previstos, con un perjuicio análogo a quien se le aplicara, ni tampoco podía ser limitado para excluir casos que cayeran dentro de sus expresos términos.

Los demandados, como constataba Coke en su sentencia, se apoyaban en el texto de la concesión, ratificado por el estatuto de Enrique VIII, que era negativo, y en coherencia con lo que se acaba de decir, el tribunal no iba a excluir de la aplicación del texto estatutario a quien, de conformidad con el mismo, no podía ser excluido. El razonamiento del tribunal es muy claro al respecto:

“(T)hey ---se puede leer en la sentencia en alusión a los demandados--- did relie upon the Letter of the grant, ratified by the said Act of $14 \mathrm{H}$. 8. which is in the negative, scil. (scilicet) Nemo in dicta civitate ecerceat .... dictam facultatem nisi ad hoc per praedict' praesidentem et communitatem,.... admissus sit.... And this proposition is a general negative, and Generale dictum est generaliter intelligendum; and nemo excludeth all; and therefore a Doctor of the one University or the other, is prohibited within this negative word Nemo. And many cases were put, where negative Statutes shall be taken stricte et exclusive, which I do not think necessary to be recited" ${ }^{\prime \prime 2}$. (Ellos se apoyaban en la letra de la concesión, ratificada por la mencionada Ley de Enrique VIII, que está en negativo, especialmente "Nadie en la citada ciudad.... ejercería la misma facultad a menos que se le admitiera a ello por el antes mencionado presidente y comunidad....". Y esta proposición es una negación general y una declaración general debe entenderse generalmente y "nadie" excluye a todos, y por lo tanto, a un doctor de una Universidad o de otra le está prohibido dentro de esta palabra negativa

\footnotetext{
${ }^{81}$ THORNE, S. E.: "Dr. Bonham's Case", op. cit., p. 545.

${ }^{82}$ Apud The Selected Writings and Speeches of Sir Edward Coke, op. cit., Vol. One, p. 270.
} 
"nadie". Y muchos casos se podrían presentar donde los estatutos negativos fueron considerados estricta y excluyentemente, que no creo necesario que sean mencionados).

De esta forma, una posible vía interpretativa con la que resolver la demanda a favor de Bonham quedaba cerrada. Por si hubiese alguna duda, otra sección de la Ley de Enrique VIII, que se refería a las personas que practicaran la medicina fuera de Londres, incidía aún más, y en la misma dirección, sobre la cuestión. Tales personas habían de ser asimismo examinadas por los censores del College, y obtener de los mismos la pertinente acreditación, y ello con la sola salvedad de los graduados por las Universidades de Oxford y Cambridge, a quienes había de serles permitido el ejercicio de la medicina fuera de la ciudad de Londres y del área de siete millas que se incluía dentro de la ciudad, sin examen alguno previo. Como es obvio, el que esta salvedad no contemplase la ciudad de Londres y el área de siete millas que la circundaba, que a estos efectos quedaba equiparado a la misma, dejaba meridianamente claro, que el ejercicio de la medicina en esa ciudad no eximía a los graduados por Oxford y Cambridge del preceptivo examen ${ }^{83}$.

III. La mayoría del tribunal, no obstante la indiscutible racionalidad de la interpretación del Justice Daniel, iba a buscar otros cauces de resolución del litigio. Coke iba a poner la vista en la interpretación de las cartas patente del College. Como antes se dijo, a tal efecto iba a atender a las dos cláusulas que tenían relación con la causa sub iudice.

Por la primera de ellas se disponía que nadie ejerciera la medicina en la ciudad de Londres si no era admitido para ello previamente por el College. Si no obstante carecer de tal autorización se practicaba la medicina, se incurría en un ejercicio ilícito de la misma (illicite practice), que era sancionado con una multa de 100 chelines por cada mes de ejercicio. La segunda cláusula establecía que el College ejercería la supervisión, la investigación, la corrección y dirección de todos los médicos de la ciudad, incluyendo a todos los médicos extranjeros que ejercieran en ella, disponiendo al efecto de la facultad de sancionarlos por una

\footnotetext{
${ }^{83}$ El Justice Daniel no suscribiría esta interpretación, basándose para ello en un argumento rebosante de racionalidad y sentido común, al considerar al respecto que: "(A) doctor of Oxford or Cambridge is not restrained by the statute, but may practice in London or in whatever place he pleases. For an nferior college may not examine him when he has been allowed before by letter approbation...." (Un doctor por Oxford o Cambridge no está restringido por el estatuto, sino que puede practicar en Londres o en cualquier otro lugar que desee. Pues un colegio inferior no puede examinarle cuando le ha sido permitido antes por una superior aprobación.....). Apud GRAY, Charles M.: "Bonham's Case Reviewed", op. cit., p. 39.
} 
práctica inadecuada (improper practice) mediante la imposición de multas, encarcelamiento u otras medidas razonables y adecuadas. Coke, anticipémoslo ya, iba a llegar a la conclusión de que los censores, a la vista de las cartas patente, carecían de la facultad de multar o encarcelar a un médico competente por la mera práctica ilícita de la medicina en Londres, esto es, por su ejercicio sin haber obtenido previamente la pertinente licencia del College. Y para llegar a tal conclusión se iba a apoyar en los cinco argumentos siguientes:

A) Las dos cláusulas anteriormente mencionadas eran absolutas, perfectas y distintas, y en cuanto cláusulas paralelas, la una no se extendía a la otra, pues mientras a la primera se vinculaba una precisa sanción de 100 chelines, ninguna sanción definida se vinculaba a la segunda. Coke viene a decirnos, que la intención de los redactores del estatuto con la segunda cláusula debía ser la de disponer sanciones para una práctica médica inexperta, inadecuada (malpractice), sanciones que variarían en función de los perjuicios causados por esa mala práctica, por lo que los redactores del texto dejaban al Colegio la fijación del castigo en cada caso ("the King and the makers of the Act, ---se lee en la sentencia--- cannot, for so uncertain offence impose a certainty of the fine, or time of imprisonment, but leave it to the Censors to punish such offences, secundum quatitatem delicti, which is included in these words"). El principio de proporcionalidad latía intensamente bajo esta argumentación de Coke, una prueba más de la modernidad de la argumentación jurídica de este grandísimo Juez.

B) El daño que deriva de la práctica inadecuada concierne al cuerpo de la persona, y por lo tanto es razonable que el infractor deba ser castigado en su propio cuerpo, esto es, con prisión. Pero quien practica la medicina en Londres de buen modo ("but he who practiceth Physick in London in a good manner"), aunque lo haga sin licencia, no produce sin embargo ningún perjuicio en el cuerpo de un hombre. En el fondo de este razonamiento latía, como bien se ha puesto de relieve ${ }^{84}$, una suerte de lex talionis.

C) La primera cláusula (como ya dijimos) establece el plazo de un mes, de tal modo que una persona no vulnera el estatuto a menos que practique la medicina en la ciudad de

\footnotetext{
${ }^{84}$ BOYER, Allen Dillard: “<Understanding, Authority, and Will>...”, op. cit., p. 83.
} 
Londres o en las siete millas que la circundan durante menos de un mes. Pero ningún plazo se fija en la segunda cláusula ("but the clause of non bene exequendo..., doth not prescribe any time certain"), y si una persona ejerce inadecuadamente aunque sea por un plazo inferior a un mes, sin duda, sería objeto de castigo. Coke aduce además que la ley encontraba una sólida razón al hacer esta distinción, pues diversos nobles y caballeros, al igual que otras personas, iban en diversas ocasiones a Londres desde otras partes del país, y hallándose en la ciudad se veían afectados por enfermedades, e inmediatamente enviaban a buscar a los médicos de sus ciudades, pues ellos conocían sus cuerpos y la causa de sus enfermedades, por lo que añade Coke que "it was never the meaning of the Act to barr any one of his own Physician" (no fue nunca el sentido de la ley prohibir a nadie su propio médico).

D) Los censores no pueden ser jueces, secretarios y partes ("The Censors, cannot be Judges, Ministers, and parties"); jueces para dictar sentencia, secretarios para hacer requerimientos, y partes para tener la mitad de la confiscación (esto es, de la multa), "quia aliquis non debet esse Judex in propria causa, imo iniquum est aliquem sui rei esse judicem"(porque nadie debe ser juez en su propia causa, es una injusticia para cualquiera ser el juez de su propia propiedad), y uno no puede ser juez y fiscal para cualquiera de las partes ("and one cannot be Judge and Attorney for any of the parties"). La idea de que debía de haber, al menos, tres personas, el demandante, el demandado y el juez, para que pudiera existir un caso judicial y alcanzarse una sentencia, e implícita en ella, la de que la decisión no podía alcanzarse adecuadamente a menos que las tres personas de la trinidad fueran distintas, estaba perfectamente asumida desde tiempo atrás ${ }^{85}$. Henry de Bracton, en el siglo XIII, en su ya mencionada De Legibus et consuetudinibus Angliae, escribiría que un juez sería descalificado con base a fundamentos tales como el parentesco, la enemistad o la amistad con una de las partes, o a causa de que estuviere subordinado en su "status" a una de las partes, o hubiere actuado como su abogado, si bien parece que Bracton tomó prestada esta consideración del Derecho canónico, y no cabe olvidar que mientras los tribunales eclesiásticos aplicaban claramente estas reglas para la recusación del suspectus iudex, no

\footnotetext{
${ }^{85}$ Ya Fleta había escrito al respecto: "Est autem iudicium trinus actum trium personarum ad minus, actoris, iudicis et rei, sine quibus legitime consistere non potest". Apud YALE, D. E. C.: "Iudex in propria causa: An Historical Excursus", en Cambridge Law Journal (Cambridge L. J.), Vol. 33, 1974, pp. 80 y ss.; en concreto, p. 80 .
} 
parece que ese fuera el caso en los tribunales ingleses, o por lo menos no se menciona ningún caso en que análogas reglas hubieren sido aplicadas en los Year Books ${ }^{86}$.

Justamente tras la reflexión precedentemente expuesta, Coke añadía el celebérrimo párrafo de esta sentencia:

"And it appeareth in our Books, that in many Cases, the Common Law doth controll Acts of Parliament, and sometimes shall adjudge them to be void: for when an Act of Parliament is against Common right and reason, or repugnant, or impossible to be performed, the Common Law will controll it, and adjudge such Act to be void" ${ }^{\prime 7}$. (Y aparece en nuestros libros, que en muchos casos el common law controla las leyes del Parlamento, y a veces debe declararlas nulas, pues cuando una ley del Parlamento es contraria al Derecho común y la razón, contradictoria, o imposible de ser cumplida, el common law debe tener autoridad sobre ella y declarar que tal ley es nula).

A modo justamente de verificación empírica de la referencia que hace Coke a unos hipotéticos precedentes jurisprudenciales recogidos en los Year Books que avalarían su doctrina, el Chief Justice se detiene en algunos antiguos casos. Por la importancia de esta cuestión, la vamos a soslayar de momento, para tratarla en un específico epígrafe posterior. Tampoco nos detendremos por ahora en las muchas, y bastante contradictorias, reflexiones a que ha dado lugar este pasaje,

E) El último argumento gira en torno al principio de que nadie puede ser castigado dos veces por el mismo delito o falta. Coke razona, que si las dos cláusulas de las cartas patente no fueran distintas, un médico que ejerciera sin la pertinente licencia e inadecuadamente sería objeto de una multa de 100 chelines, fijada por el estatuto, una vez que hubiera practicado la medicina durante un mes, pero también debería ser castigado al mismo tiempo por la previsión de la segunda cláusula. Pero de ello se seguirían dos absurdos ("two absurdities"). El primero de ellos sería que una persona debería ser castigada no sólo dos veces, sino muchas veces por una única falta. Y añade Coke, "the Divine saith, Quod Deus

\footnotetext{
${ }^{86}$ Ibidem, p. 81.

${ }^{87}$ Apud The Selected Writings and Speeches of Sir Edward Coke, op. cit., Vol. One, p. 275. En el texto transcrito en la obra figura el término "somtimes", que hemos cambiado por "sometimes" por entender que puede tratarse de un error tipográfico, aunque no descartamos que pueda ser inglés antiguo. Por lo demás, mantenemos otros términos que se reiteran en los textos de Coke y que entendemos que responden a una forma antigua del idioma.
} 
non agit bis in idipsum; and the Law saith, Nemo debet bis puniri pro uno delicto" (el teólogo dice, "que Dios no procede dos veces contra la misma persona", y el Derecho dice, "nadie debe ser castigado dos veces por un delito"). Sería absurdo asimismo castigar por la primera cláusula la práctica de la medicina por un mes y no por un tiempo menor, y por la segunda castigar la práctica no solamente por un mes sino por cualquier tiempo, incluso por un solo día, pues si así fuera, el ejerciente de la práctica médica será castigado por la primera cláusula con una confiscación (multa) y por la segunda con multa y prisión, sin limitación.

IV. Estos son los argumentos que nuestro Juez presentó para fundamentar que las dos cláusulas de la patente eran distintas, y que por lo mismo la facultad del College para decidir la prisión de un ejerciente de la medicina estaba confinada a los médicos culpables de una práctica inadecuada o negligente (malpractice). La interpretación de Coke nos parece por entero pertinente, pues es patente que los supuestos contemplados por cada una de las dos cláusulas eran de una muy dispar gravedad, ya que mientras la primera se refería a una infracción que hoy podríamos tildar de meramente administrativa, la segunda contemplaba un supuesto incardinable en el ámbito de lo penal. Parece perfectamente razonable que sólo a este último caso se anude la sanción de privación de libertad. De ahí que asista toda la razón a Rey Martínez, hasta donde conocemos, único autor español que ha estudiado este tema, cuando considera ${ }^{88}$, que la lectura que Coke va a hacer de los textos legales es una interpretación garantista de la libertad y por lo tanto moderna, lo que a su vez, siguiendo la estela de Thorne, le lleva a considerar el razonamiento del Chief Justice como de mera legalidad, rechazando implícitamente, esta vez de modo bastante más discutible, que se trate de un razonamiento que sustente la doctrina del control de constitucionalidad. Al margen ya de ello, sobre lo que volveremos más adelante, lo cierto sería que la argumentación de Coke conducía a la conclusión de que la prisión del Dr. Bonham había sido ilegal, pues el Colegio había invocado su autoridad para sancionar una mala práctica, no obstante haberse limitado la falta del Dr. Bonham, como mucho, a ejercer la medicina sin la licencia del Colegio.

Con la salvedad del cuarto argumento, de mucha más amplia proyección, los restantes parecen directamente encaminados hacia esa finalidad de considerar la ilegalidad del

\footnotetext{
${ }^{88}$ REY MARTÍNEZ, Fernando: "Una relectura del Dr. Bonham's Case y de la aportación de Sir Edward Coke a la creación de la judicial review", en Revista Peruana de Derecho Público, Año 8, núm. 14, Enero/Junio 2007, pp. 47 y ss.; en concreto, p. 57.
} 
encarcelamiento de Bonham ${ }^{89}$, aunque no faltan autores, como es el caso de Stoner $^{90}$, que consideran que realmente los cinco argumentos se dan en el contexto de apoyar una cierta interpretación del estatuto. Aun cuando pueda admitirse genéricamente esta reflexión, un análisis pausado de los cinco argumentos, como mínimo, nos pone de relieve, que el cuarto argumento no parece incidir tanto sobre la diferenciación de las dos cláusulas del estatuto, cuanto sobre la improcedencia de los censores para, incluso, imponer multas en cualquiera de los supuestos contemplados estatutariamente. Este argumento creemos que proyecta su vuelo a una altura muy superior a la de los otros cuatro, y ello con independencia de la precisa intención que Coke tuviera con el mismo, tema que trataremos más adelante. Podría pensarse que el cuarto argumento, al referirse a un principio tan esencial a la justicia como era el de que nadie puede juzgar el propio caso, principio que claramente había sido transgredido, estaba dando por cerrado el caso. Pero como aduce la doctrina, lo esencial en esta etapa no era cómo se había comportado el College, algo que se trataba después, sino cuál era la ley y, de modo particular, cómo debía aplicarse el estatuto, dando adecuada respuesta a si las cartas patente y el estatuto confirmatorio permitían este modo de proceder.

Como ya indicamos, Coke parece compendiar, y a la par fundamentar, sus argumentaciones en dos máximas jurídicas" ${ }^{91} 1^{\text {a) }}$ “Generalis Clausula non porrigitur ad ea quae specialiter sunt comprehensa" (Una cláusula general no tiene que extenderse a algo que es especialmente mencionado). Y 2 $2^{\mathrm{a}}$ ) "Verba posteriora propter certitudinem addita ad priora quae certitudine indigent sunt referenda" (Las palabras subsiguientes, añadidas con el propósito de certeza, tienen que referirse de nuevo a las previas palabras que carecen de esa certeza). Estas máximas, ciertamente, parecen estrechamente vinculadas con la interpretación estatutaria. Al referirse a la primera de ellas, y después de mencionar un ejemplo relativo al Derecho de propiedad, Coke escribe: "if it be so in a deed, afortiori, it shall be so in an Act of Parliament, which (as a Will) is to be expounded according to the intention of the makers" (si fuera así en una escritura, a fortiori, será así en una ley del Parlamento, que ---como un testamento--- tiene que explicarse de acuerdo con la intención de quienes la han hecho) ${ }^{92}$.

\footnotetext{
${ }^{89}$ De modo análogo se pronuncia S. E. THORNE, en "Dr. Bonham's Case”, op. cit., p. 547.

${ }^{90}$ STONER, Jr., James R.: Common Law and Liberal Theory..., op. cit., p. 51.

${ }_{91}^{91}$ Apud The Selected Writings and Speeches of Sir Edward Coke, op. cit., Vol. One, pp. 277-278.

${ }^{92}$ No vamos a entrar en el análisis del segundo razonamiento de la sentencia, pues creemos que es marginal al tema central de nuestro estudio, que se vería aún más alargado, e incluso es secundario para la propia sentencia. Las seis causas mencionadas por Coke, en que se asienta este segundo razonamiento, son de orden básicamente
} 


\section{Los precedentes jurisprudenciales en que Coke apoya su dictum.}

Inmediatamente después del celebérrimo dictum de Coke, éste se refiere a cinco casos que pueden servir de precedentes jurisprudenciales en que apoyarlo, si bien los dos últimos pueden en realidad reconducirse a uno tan sólo, el Strowd's Case, puesto que tanto éste como el otro, anónimo, se referían al mismo estatuto. A ellos hay que añadir el Thomas Tregor's Case, el caso Cessavir 42 y el caso Annuity 41, también conocido como el Case of the Seals. Plucknett, y a partir de él otros autores, se han ocupado de investigar hasta qué punto los casos mencionados podrían apoyar el célebre pasaje y en qué sentido. Los Year Books law han servido de base para la investigación emprendida por la doctrina norteamericana, la que más se ha ocupado del tema.

\section{A) El Thomas Tregor's Case.}

El primero de los casos mencionados en la sentencia es el conocido como Thomas Tregor's case. La cita de este caso viene a recordar un dictum del Juez Herle, quien afirmó: "There are some statutes made which he himself who made them does not will to put into effect", términos que en sus Reports Coke reformula así: "Some Statutes are made against Common Law and right, which those who made them, would not put them in execution" 93 .

El significado de este caso ha sido objeto de una considerable discusión. Plucknett pondría de relieve ${ }^{94}$, que el Chief Justice iba a citar incorrectamente el dictum al transcribir inicialmente el texto del Year Book ${ }^{95}$ así: "Herle saith some statutes are made against law and right, which those who made them perceiving, would not put them into execution". Como es obvio, las palabras en cursivas muestran las interpolaciones de Coke, desconocidas por el original, que vienen a introducir una cierta idea de un Derecho superior que no parece que el Juez Herle albergara, pues el único sentido que razonablemente puede otorgarse a las palabras de Herle es que algunas veces el legislador se ha arrepentido de una parte irreflexiva de su trabajo y se ha mostrado contento de que el mismo se convierta en una "dead letter". McIlwain observaría, que el error de Coke pudo deberse a que transcribiera de memoria el

procesal. Pueden verse en The Selected Writings and Speeches of Sir Edeward Coke, op. cit., Vol. One, pp. 280281.

${ }^{93}$ Apud The Selected Writings and Speeches of Sir Edward Coke, op. cit., Vol. One, pp. 275-276.

${ }^{94}$ PLUCKNETT, Theodore F. T.: "Bonham's Case and Judicial Review”, op. cit., p. 35.

${ }^{95}$ En el Year Book el texto original es el siguiente: "Ils sont ascun statutes faitz que celuy mesme que les fist ne les voleit pas mettre en fait". Apud GRAY, Charles M.: "Bonham's Case Reviewed", op. cit., p. 47, nota 23. 
texto de Herle, aunque nos parece más probable que con esa adición nuestro Chief Justice estuviese tratando de revelar su propia concepción ${ }^{96}$, esto es, ofreciendo una prueba de la facultad de los jueces de dejar de lado los estatutos que consideraren contrarios al common law.

Boudin, de modo rotundo, iba a apuntar que aquí no hay una decisión que declare nula una ley del Parlamento, para añadir más adelante un tanto fuera de tono, que "Coke falsified the record in order to make it appear that the idea of a paramount law and right, superior to the concrete law of the lawgiver was well recognized in English jurisprudence" 97 . En definitiva, este primer precedente parece hallarse lejos de ser convincente.

\section{B) El caso Cessavit 42.}

El segundo precedente es un caso anónimo impreso por Fitzherbert en su "Compendio" (Abridgement), procedente de un Year Book inédito, e identificado como Cessavit 42. Quien sin duda es la mayor autoridad en el estudio de estos antecedentes, Plucknett, considera que este caso va mucho más lejos en lo que atañe al apoyo a la tesis de Coke de lo que lo hace el Tregor's case, y ello no obstante el hecho de que en el Graunde Abridgement de Fitzherbert este caso no ocupa sino unas pocas líneas y no muy inteligibles, no obstante lo cual, posteriores investigaciones han ido incrementando su valor. Además, incluso en la forma en que aparece en el texto de Fitzherbert, resulta claro que la decisión se halla en completo acuerdo con otra de un caso anterior, Copper v. Gederings, que está recogido en las actas con mucho más detenimiento.

Sin entrar en muchos detalles, diremos que este caso implicaba un writ of cessavit formulado en el reinado de Eduardo III (Rey de Inglaterra entre 1327 y 1377) con base en segundo Estatuto de Westminster. El estatuto facultaba a un señor (lord) para formalizar un writ de este tipo con vistas a recuperar su propiedad arrendada en caso de que el arrendatario hubiere dejado de cumplir fielmente el servicio convenido y de pagar los alquileres sobre la propiedad durante dos años. El texto estatutario disponía, que el derecho de acción a través de un writ of cessavit pasaría del señor a su heredero. En el caso en cuestión, falleció el señor y su heredero, ante el incumplimiento del arrendatario, presentó el writ, que sin embargo fue

\footnotetext{
${ }^{96}$ En análogo sentido, MacKay escribe: "It is clearly Coke's theory, whether or not it is Herle's". MacKAY, R. A.: "Coke-Parliamentary Sovereignty or the Supremacy of Law?", op. cit., p. 223.

${ }^{97}$ BOUDIN, Louis B.: "Lord Coke and the American Doctrine of Judicial Power", op. cit., p. 238.
} 
rechazado por el Chief Justice Bereford con fundamento en que si la acción era admitida, algunos principios generales del common law se verían alterados, pues de conformidad con el common law las cantidades atrasadas debidas a su ascendiente o los servicios debidos al mismo no pertenecían al heredero, que no tenía derecho a recibirlos. Bereford iba a esgrimir, que si el writ se hubiera presentado mientras vivía el señor, el arrendatario hubiera podido entregarle los atrasos y daños antes de la decisión y mantener así su arrendamiento.

Recuerda Plucknett ${ }^{98}$, que el Juez Bereford había tenido la osadía en diversas ocasiones de incluir sus propios puntos de vista, marcadamente originales, sobre problemas jurídicos en sus decisiones, pero en este supuesto se dio la misma decisión medio siglo después en Cessavit 42, siendo debidamente conservada en los Year Books como el Derecho definitivo sobre la cuestión. No se trataba pues, de un mero capricho del Juez, sino de una cadena de decisiones judiciales que se extendía desde mediados del siglo XIV hasta los propios días de Coke. Y en estos supuestos, los tribunales, claramente, habían hecho caso omiso del inequívoco significado de un texto estatutario, si bien en el informe ("report") del litigio el estatuto no se considera nulo, sino que simplemente se ignora, lo que, según se ha dicho ${ }^{99}$, nos sitúa ante un caso de interpretación estricta, en conformidad con la cual el supuesto de hecho se declara hallarse fuera del ámbito estatutario; el estatuto no es nulo sino tan sólo inaplicable. La alusión que Coke hará a la nulidad será fruto de su propia cosecha doctrinal. Boudin insistiría en este dato de que no hubo decisión declarando nula una ley del Parlamento, como también en que, en sí mismo, el caso no dice nada acerca de que la ley en cuestión fuera contraria al common right and reason, concluyendo con un dicho que atribuye a los abogados de su época: "No opinion covers a multitude of sins" 100.

\section{C) El caso Annuity 41.}

El tercer precedente citado por Coke es otro caso recogido por Fitzherbert, el llamado Annuity $41^{101}$, un caso decidido durante el vigésimo séptimo año del reinado de Enrique VI (su reinado se extendió entre 1422 y 1461), que implicaba la interpretación y

\footnotetext{
${ }^{98}$ PLUCKNETT, Theodore F. T.: "Bonham's Case and Judicial Review”, op. cit., p. 36.

${ }^{99}$ MacKAY, R. A.: “Coke-Parliamentary Sovereignty or...”, op. cit., p. 224.

${ }^{100}$ BOUDIN, Louis B.: "Lord Coke and the American Doctrine...", op. cit., pp. 238-239.

${ }^{101}$ Boudin recuerda que este caso es asimismo conocido como Rous vs. an Abbot, y también como el Case of the Seals. BOUDIN, Louis B.: "Lord Coke and the American Doctrine...", op. cit., p. 239.
} 
aplicación del estatuto De Asportatis Religiosorum, también conocido como el Statute of Carlisle, promulgado en 1307 por el Rey Eduardo I.

El texto estatutario abordaba un problema jurídico relativo a asuntos eclesiásticos que había desencadenado numerosos procesos ante los tribunales. Muchas casas religiosas pequeñas carecían de un sello común, por lo que, llegado el caso, contendían con el sello personal de su director. Así, inevitablemente, surgían problemas, como por ejemplo, el de si un documento particular de conformidad con el sello del abad era una escritura personal del propio abad o, por el contrario, se trataba de una escritura de la corporación eclesiástica que el abad presidía, vinculando en tal caso a toda la comunidad y no sólo al abad. Para hacer frente a este problema, el estatuto ordenaba a todas las casas religiosas de los Cistercienses y de los Agustinos disponer de un sello común para sus actos corporativos y colocar tal sello bajo la custodia del prior y de los cuatro hermanos más respetables de la comunidad, quienes habían de mantenerlo asegurado, al margen del sello privado del abad, de modo tal que el abad no pudiera usarlo sin conocimiento de la comunidad. A través de esta fórmula se pretendía lograr que el sello conventual fuera una prueba infalible de la concurrencia de la voluntad de la comunidad en el acto de quien estaba a su frente.

El estatuto podía haberse limitado a añadir a la regulación ya comentada los actos conventuales que requerían del sello conventual, pero fue mucho más lejos, al disponer la anulación de todos los actos formalizados cuando el sello conventual no se mantuviese bajo la custodia del prior y de los cuatro hermanos, con lo que se pretendía poner un freno a los abades que utilizaban el sello conventual sin conocimiento de la comunidad. Tal disposición era obviamente de difícil cumplimiento, a menos que existiera una estrecha cooperación con la Iglesia.

La aludida dificultad se puso formalmente de manifiesto en 1449, en el caso que nos ocupa, que se originó al recurrir un convento al estatuto en cuestión para requerir la anulación de una escritura que hacía recaer sobre la comunidad el pago de una renta anual, con base en que al tiempo en que la escritura se hizo, el abad entonces al frente de la comunidad no había mantenido el sello común bajo la custodia estatutariamente prevista. El tribunal consideró, sin embargo, que la escritura cuestionada era válida, sin atender a las disposiciones estatutarias.

La argumentación del tribunal fue doble. Por un lado, consideró la imposibilidad de cumplir lo requerido por el estatuto, pues si el sello conventual era mantenido bajo la 
del prior y de cuatro hermanos, el abad, que era el miembro superior de la comunidad, se veía imposibilitado de utilizarlo. Por otro, con un argumento más convincente, adujo el tribunal, que con esta disposición estatutaria un convento podía prácticamente evitar cualquiera de los actos en que hubiera sido parte mediante la simple alegación de que el sello conventual no se hallaba bajo la adecuada custodia. Como señala Gray ${ }^{102}$, la falta en el estatuto era su contradicción o su imposibilidad de cumplimiento en su sentido más simple. En el texto manuscrito de Coke (del Bonham's case) a que alude este autor, el Chief Justice habla de un "statute void for inconvenience and impertinency", términos que parece que no deben entenderse como alusivos a un fundamento más amplio que el de "repugnancy" para la anulación del estatuto.

Plucknett ha llamado la atención sobre varias cuestiones ${ }^{103}$. Ante todo, el caso no parece que se cerrara con una sentencia, sino con una mera resolución; en realidad, según Stoner ${ }^{104}$, lo que acontece es que el "report" del caso tan sólo nos ofrece el debate de los jueces sobre la cuestión, pero no su decisión. En segundo término, la palabra "void" no se encuentra usada respecto del estatuto. En tercer lugar, no ha faltado quien, como Brinton Coxe, a fines del siglo XIX, especulara (en su obra Judicial Power and Unconstitutional Legislation) acerca de si la decisión se vio influenciada por consideraciones relativas al Derecho canónico, aunque esta especulación le parece menos convincente al Profesor de Harvard. En fin, la excusa dada por los jueces para su resolución (que no sentencia) no será la imposibilidad de aplicar la ley, como declararía Coke. También Smith entiende ${ }^{105}$, que la “impossibility” mencionada en este caso parecía haberse desarrollado más como una fícción jurídica por los propios jueces que como auténtica imposibilidad jurídica sustentada en rigurosos principios de Derecho. Todo ello llevó a Plucknett a cuestionarse si este caso podía considerarse una autoridad en la que Coke pudiera apoyar su dictum. Por su parte, Boudin, de modo inequívoco, considera que este caso carece de relevancia en cuanto a la cuestión que nos interesa ${ }^{106}$.

La escasez de los argumentos que se conocen en pro y en contra hace arriesgado pensar que se puede llegar a reconstruir el sentir del tribunal sobre la cuestión, todo lo cual

\footnotetext{
102 GRAY, Charles M.: "Bonham's Case Reviewed”, op. cit., p. 47.

${ }^{103}$ PLUCKNETT, Theodore F. T.: “Bonham's Case and Judicial Review”, op. cit., pp. 39-40.

${ }^{104}$ STONER, Jr., James R.: Common Law and Liberal Theory..., op. cit., p. 56.

105 SMITH, II', George P.: "Dr. Bonham's Case and the Modern Significance...", op. cit., p. 308.

${ }^{106}$ BOUDIN, Louis B.: "Lord Coke and the American Doctrine...", op. cit., p. 239.
} 
conduce a Plucknett a concluir que el caso contiene demasiados factores desconocidos como para ser utilizado con cierto grado de confianza y seguridad, aunque, manifiestamente, no fuera éste el punto de vista predominante ni por parte de Coke ni de la mayoría de sus contemporáneos. No puede dudarse, que en el siglo XVII este caso fuera considerado sin duda de ningún género un caso digno de ser tomado en consideración en la cuestión aquí abordada.

\section{D) El Strowd's Case.}

Los dos últimos casos pueden en realidad reconducirse a tan sólo uno, pues ambos se refieren a la misma norma estatutaria, que se identifica como "1 Edw. VI, Chap. 14", norma que venía referida a la confiscación de la propiedad de la Iglesia con ocasión de la English Reformation. Coke se iba a aproximar aquí al tema desde una perspectiva diferente. En los días de los primeros Year Books, el Rey era "prerogative", lo que era tanto como decir, que había un cierto punto más allá del cual el Derecho ordinario no le era de aplicación. ¿Qué ocurría entonces si una norma estatutaria colisionaba con la prerrogativa de la Corona?

Tal situación se originó con ocasión del amplio vuelco de títulos jurídicos derivado de la supresión con la "Reforma" de las casas religiosas y de las capellanías ${ }^{107}$. De resultas de varios estatutos, un amplio número de propiedades de tierras pasó a manos de la Corona, permaneciendo en poder de la misma hasta tanto eran otorgadas a determinados súbditos mediante "royal letters patent". Muchas de estas tierras se hallaban sujetas a complejas obligaciones e incidencias que los estatutos intentaban resolver. Por ejemplo, muchas de estas tierras no sólo sostenían a sus propietarios eclesiásticos, sino que también se hallaban sujetas a diversas rentas o cargas de alquiler ("rent charges"), que se habían de pagar a laicos que no se hallaban vinculados de ningún modo con las fundaciones religiosas. Algunas tierras se hallaban sometidas a una peculiar carga conocida como "rent service", y aquí iban a surgir las complicaciones. El "rent service" era un alquiler reservado al momento de constituirse un feudo, que se debía a un señor ("lord”) por su arrendatario en virtud de su relación feudal y de la lealtad que la misma implicaba. No era un precio, sino más bien un servicio feudal, y el señor podía exigirlo mediante el embargo, (aun cuando no hubiera una cláusula de embargo en el feudo que le autorizara a ello) pues aunque la tierra fuera considerada por el arrendatario en plena propiedad, sin embargo, también se consideraba por el señor "en servicio", y el señor

\footnotetext{
${ }^{107}$ PLUCKNETT, Theodore F. T.: "Bonham's Case and Judicial Review”, op. cit., pp. 41-42.
} 
podía embargarla dentro de su propio feudo. Innecesario es decir, que cuando una tierra sujeta a este tipo de vínculos jurídicos llegaba a manos del Rey había de sufrir un cambio. El Rey, que era "prerogative", no podía rebajarse a realizar servicios a ninguno de sus súbditos.

El estatuto para la supresión de las capellanías, en su esfuerzo para ser tan justo como fuera posible, contenía una salvaguardia general de los derechos a los alquileres (incluyendo los "rent services") que tuvieren todas las personas en relación con las tierras de la capellanía. Ello entrañaba un patente conflicto entre la prerrogativa regia y los derechos salvaguardados por el estatuto, pues la primera extinguía los alquileres, el segundo los salvaguardaba.

Coke iba a mencionar unos casos acontecidos bajo el reinado de Isabel I. El primero era un caso anónimo fechado en 1572. El informe eran tan breve como sigue:

"Memorandum. That it was resolved by the opinion of the Court in Bench, That the seigniory of obit land, or chartry land. is extinct by the possession of the King, by the act of I E. 6. (c. 14) notwithstanding the saving in the act; propter absurditatem \& $c . " 108$. (Que se resolvió por la sentencia del Tribunal, que el señorío de la tierra del obituario o de la capellanía, está extinguido por la posesión del Rey, por la Ley de Eduardo I, no obstante la salvedad en la ley a causa de su absurdo).

El breve informe nos sitúa ante un tipo de defecto legal que puede añadirse a la "impertinence" o a la "impossibility"; nos referimos a la "absurdity". La decisión no es tan radical como pudiera parecer, pues en el "report" se explica más adelante que, aún extinguiéndose el arrendamiento, los "rent services" que eran parte del mismo podían exigirse por el "lord" al Rey, al que había ido la cesión de la tierra, por medio del embargo. Se daba así una curiosa situación. El tribunal, con gran atrevimiento, rehusaba reconocer las expresas palabras del estatuto en favor de los "rent services" y los declaraba rotundamente extintos, non obstante la ley, pero lo que se llevaba con una mano lo restauraba prudentemente con la otra, pues admitía que el antiguo señor ("the quondam lord") todavía podía exigir su alquiler por medio del embargo.

El segundo caso, el conocido como Strowd's case, iba a dar una respuesta más acorde con sus justas proporciones. El tribunal, en pocas palabras, iba a resolver la compleja

${ }^{108}$ Apud PLUCKNETT, Theodore F. T.: "Bonham's Case...", op. cit., p. 43. 
cuestión interpretando "rent service" de modo tal que viniera a suponer su equivalente económico, esto es, "rent charge". Este resultado, como dice Gray ${ }^{109}$, podía explicarse por la desgana del tribunal de salvar una norma estatutaria al precio de un principio establecido por el common law, especialmente uno relativo a la prerrogativa regia, si bien, para MacKay ${ }^{110}$, no se trataba tanto de un principio del common law, pues a su juicio ninguno se hallaba implicado, como tan sólo de un fundamento asentado en el "common sense", pues el simple sentido común mostraba que el Rey no podía ser el servidor de un súbdito.

La decisión viene a ser idéntica a la del caso anónimo inmediatamente antes citado, omitiendo la retórica del mismo, de lo que da prueba la supresión del párrafo de ese otro caso "notwithstanding the saving in the act". Ahora el tribunal procede a interpretar el estatuto con la consecuencia que unas líneas atrás indicamos, que, recordémoslo en pocas palabras, no es otra que la de sustituir los "rent services" por los "rent charges". No obstante, Coke plasmaba en su "report" que el tribunal había considerado nulo el estatuto en cuestión con base en su carácter absurdo y en la imposibilidad de su cumplimiento.

Boudin pondría de relieve ${ }^{111}$ que, como una cuestión de hecho, en ambos casos, el tribunal se había limitado a aplicar las previsiones del estatuto, por lo que difícilmente podían utilizarse por Coke como precedentes en apoyo de su dictum. ¿Porqué recurrió entonces a ellos Coke? Pues posiblemente, en lo que hace al primero de los casos, por esa afirmación del tribunal de que una ley que hiciera pagar al Rey un "rent service" no podía ser aplicada por razón de su absurdo ("because of absurdity"). No otra había sido la posición de Plucknett, quien había manifestado, que en ninguna parte ("nowhere") de las actas de este caso (el Strowd's case) aparece el dogma de Coke de un control por el common law con la consiguiente anulación del estatuto con base en tal fundamento ${ }^{112}$.

\section{E) Breve recapitulación sobre estos precedentes.}

En una recapitulación sobre los precedentes expuestos, resulta evidente que el Tregor's case demuestra muy poco, por no decir que nada, respecto a la supuesta enunciación en el pasaje que nos ocupa de una teoría constitucional de la judicial review; distinto sería si

\footnotetext{
${ }^{109}$ GRAY, Charles M.: "Bonham's Case Reviewed”, op. cit., p. 48.

${ }_{110}$ MacKAY, R. A.: “Coke-Parliamentary Sovereignty or...,", op. cit., p. 224.

${ }^{111}$ BOUDIN, Louis B.: "Lord Coke and the American Doctrine...", op. cit., p. 241.

112 PLUCKNETT, Theodore F. T.: "Bonham's Case...", op. cit., p. 44.
} 
reconducimos el dictum de Coke al marco de la interpretación, pues no cabe olvidar que la declaración del Juez Herle en ese caso se sitúa en el curso de un debate sobre la interpretación de un estatuto. Ahora bien, tampoco conviene echar en el olvido un aspecto al que se refiriera Corwin $^{113}$ : tras la reflexión del Juez Herle subyacía la idea, en absoluto despreciable, de que el propio cuerpo legislativo reconocía la fuerza vinculante y anulatoria ("the binding and invalidating force") de principios externos al acto legislativo.

El caso Cessavit 42 es, por el contrario, un sólido precedente para el argumento que ahora nos interesa de Coke. Para Plucknett, es sin duda el más claro precedente, aunque no falta quien, como Stoner ${ }^{114}$, considera que este caso recibe en las manos de Coke una interpretación más limitada que la que le atribuye teóricamente el Profesor de Harvard, pues el Chief Justice consideró que la ley fue anulada tan sólo en cuanto al punto que se hallaba particularmente cuestionado (el derecho de los herederos a conseguir una cierta recuperación de los atrasos debidos a su antecesor), por lo que el propio Stoner entiende que es probable que el Chief Justice estuviera reconociendo a los jueces tan sólo la facultad de exceptuar de los términos generales de un estatuto una situación en la que una máxima del common law resultara violada, y no hay razón para excluir que esto pueda considerarse dentro de las reglas de la interpretación estatutaria. Frente a tal visión, Boyer considera ${ }^{115}$, que el caso Cessavit 42 es el único precedente que firmemente apoyaba a Edward Coke. Los Year Books nos situaban con toda claridad ante un caso que se remontaba tres siglos atrás en el que el tribunal había rehusado permitir a un demandante mantener una acción que el estatuto en cuestión permitía, lo que entrañaba que los common-law judges habían rehusado dar pleno efecto jurídico al texto de un estatuto en vigor.

En cuanto al caso Annuity 41, Smith lo considera ${ }^{116}$ de poca importancia a causa de la extrema arbitrariedad del tribunal, al basar su decisión en la imposibilidad legal de cumplimiento del estatuto, opinión harto discutible, mientras que Plucknett, más matizadamente, señala que aunque se había contemplado como un caso sólido, de hecho, es de un significado dudoso ${ }^{117}$. En lo que se refiere al Strowd's case y al caso anónimo parejo, no ofrecen un fundamento que refuerce la premisa básica de Coke. Boudin ha sido sin duda el

\footnotetext{
${ }^{113}$ CORWIN, Edward S.: "The <Higher Law> Background of American Constitutional Law" (II), op. cit., p. 372.

${ }^{114}$ STONER, Jr., James R.: Common Law and Liberal Theory..., op. cit., p. 57.

115 BOYER, Allen Dillard: “<Understanding, Authority, and Will>...”, op. cit., p. 84.

${ }^{116}$ SMITH, II', George P.: "Dr. Bonham's Case and the Modern Significance...”, op. cit., p. 310.

${ }^{117}$ PLUCKNETT, Theodore F. T.: "Bonham's Case...", op. cit., pp. 44-45.
} 
más ácido y radical de quienes se han pronunciado al respecto, al concluir que los muchos casos alegados por Coke como fundamento histórico de su dictum han quedado reducidos exactamente a la nada (“the many cases have dwindled to exactly nothing") ${ }^{118}$.

Así enjuiciados, podría decirse que estos casos supusieron que Coke presentara a sus colegas tan sólo dos precedentes reseñables de una cierta teoría política de la judicial review, uno bastante claro y otro con evidentes puntos de debilidad. Sin embargo, si ahora hacemos uso de fuentes que en su momento no eran utilizables, el resultado, según admite el propio Plucknett ${ }^{119}$, es más bien diferente, y ello por cuanto, aunque los hechos alegados por el Chief Justice aún pueden ser confirmados por los Year Books publicados, la teoría de la judicial review supuestamente formulada por Coke debe más bien atribuirse a su propio pensamiento jurídico antes que al de sus predecesores medievales en el Common Bench. Dicho de otro modo, el eminente Profesor de Harvard termina reconociendo, que los precedentes jurisprudenciales mencionados en el Bonham's case no otorgan un sustento suficiente para que el Chief Justice busque en ellos apoyo para su supuesta doctrina de la judicial review.

En resumen, los precedentes jurisprudenciales expuestos no terminan de ofrecer de un modo determinante el soporte en el que sustentar que en su célebre dictum Coke estaba sentando la doctrina de la judicial review tal y como iba a ser entendida siglos después en los Estados Unidos. Incluso, en cierta medida, alguno de ellos podría servir de apoyo para la tesis de que Coke estaba formulando una máxima de la interpretación estatutaria. En cualquier caso, no creemos que de estos precedentes pueda extraerse un apoyo sustancial para ninguna de las dos interpretaciones en juego.

\section{La controvertida interpretación doctrinal del célebre dictum de Coke en el cuarto argumento: ¿formulación de la teoría constitucional de la judicial review o mera enunciación de una máxima de la interpretación estatutaria?}

Llegados aquí, vamos a retornar al trascendental cuarto argumento para el primer fundamento de la sentencia, en el que se acoge el celebrado dictum de Coke sobre, supuestamente, la judicial review, pasaje que ha venido siendo considerado desde tiempo atrás, por un buen número de autores, como el acta de nacimiento de esa doctrina de la

\footnotetext{
${ }^{118}$ BOUDIN, Louis B.: "Lord Coke and the American Doctrine...", op. cit., p. 242.

${ }^{119}$ PLUCKNETT, Theodore F. T.: "Bonham's Case...”, op. cit., p. 45.
} 
revisión judicial de la legislación, aunque hayamos de admitir que el mismo no deja de suscitar fundadas dudas que oscurecen su verdadero significado. El pasaje plantea el problema nuclear de la sentencia, que parece exigir optar entre dos interpretaciones. La primera es la de que el Chief Justice pretendía decir que hay algún standard (de Derecho natural o de una parte fundamental del common law) con el que el Derecho estatutario debe hallarse conforme o, caso contrario, ser declarado nulo por los tribunales de common law. La segunda, la de que Coke tan sólo pretendía decir, que los estatutos que dispusieran algo especialmente absurdo, contradictorio, perjudicial o imposible de cumplir, debían ser interpretados (si el texto dejaba algún margen para la interpretación) estrictamente, de modo tal que vinieran a tener un significado más conveniente. Dicho en otros términos, la opción estribaba en discernir si el pasaje de Coke proclamaba el principio de la anulación judicial de los estatutos que violaran el higher law o, por el contrario, se limitaba a enunciar una máxima, un canon, de la interpretación estatutaria. En juego pues, una tesis que podríamos tildar de maximalista frente a otra minimalista.

Antes de entrar en las diferentes interpretaciones a que el dictum ha dado lugar, consideramos necesario efectuar unas consideraciones previas acerca de ciertos precedentes medievales, que quizá pueden contribuir a arrojar algo de luz sobre esta controversia.

\section{A) Algunas consideraciones previas sobre ciertos precedentes medievales.}

I. Un pensamiento generalmente común entre los historiadores del Derecho ingleses y aquellos norteamericanos que han estudiado el desarrollo medieval del Derecho inglés ha sido su insistencia en la idea medieval de la supremacía del Derecho, una idea respecto de la cual no es exagerado decir, que estuvo claramente presente por lo menos hasta los siglos XVI y XVII. El principio de corte germánico de que el Estado se hallaba vinculado a actuar de conformidad con la ley desembocó ciertamente en la visión de la ley positiva como una criatura del soberano, pero como recuerda Roscoe Pound, no cabe olvidar que todos los soberanos, los del Continente y los de fuera del mismo, se hallaban sujetos al natural law, y las normas legales que emanaban de ellos y se situaban en conflicto con el mismo, simplemente eran nulas ${ }^{120}$. A esta teoría filosófico-jurídica, puesta en una cierta armonía con

\footnotetext{
${ }^{120}$ POUND, Roscoe: "Common law and legislation”, en Harvard Law Review (Harv. L. Rev.), Vol. XXI, 19071908, pp. 383 y ss.; en concreto, pp. 390-391.
} 
el pensamiento teológico, le dio un uso corriente en su Summa Theologica Santo Tomás de Aquino, y el propio Decano de Harvard estima, que los dos precedentes del reinado de Eduardo III aportados por Coke en el Bonham's case podrían responder a esa idea de que una ley del Parlamento contraria al natural law, o lo que es en cierto modo igual, por lo menos en Inglaterra, a the law of reason; en definitiva, una ley contraria al common right and reason, había de considerarse nula.

En análoga dirección, recuerda Berger ${ }^{121}$, que la doctrina jurídica inglesa de la época consideró que el Derecho natural (the law of nature) y la Carta Magna anulaban todas aquellas leyes que se hallaban en conflicto con ellas, por lo que la apelación a un fundamental law frente a un texto estatutario en contradicción con él había de considerarse como algo por entero lógico 122 . Y Gough, por su parte, ha escrito: "Fundamental laws (and Magna Carta itself) were valued for the protection they afforded against the arbitrary power of kings"123. No ha de dejar de atenderse al hecho de que la Carta Magna fue bastante más que una simple reacción contra el gobierno de los Angevinos; fue asimismo una declaración de principios acerca de la organización del Estado feudal. Y como tal, se diseñó sobre un cuerpo común de costumbres y experiencias que, con variantes locales, era compartido por toda Europa occidental y por los Estados latinos de Europa oriental ${ }^{124}$. Y así, la experiencia común se encarnó en reglas consuetudinarias y en los law-books, y se formuló asimismo en los estatutos de aprobación parlamentaria. Especial importancia tendría a estos efectos la confirmación de la Magna Charta por el Parlamento inglés en 1369. En ese Parlamento se expresó de modo específico, que "was assented and accorded that the Great Charter and the Charter of the Forest be holden and kept in all points; and if any Statute be made to the contrary, that shall be holden for none" 125 , formulación en la que el gran historiador norteamericano McIlwain, en su clásica obra The High Court of Parliament, apreció una clara prueba de que la Carta Magna conformaba un Derecho no sólo superior, sino también inalterable.

\footnotetext{
${ }^{121}$ BERGER, Raoul: “Doctor Bonham's Case: Statutory Construction or Constitutional Theory?”, en University of Pennsylvania Law Review (U. Pa. L. Rev.), Vol. 117, 1968-1969, pp. 521 y ss.; en concreto, pp. 535-536.

${ }^{122}$ No faltan, desde luego, quienes efectuan determinadas matizaciones, como es el caso de Goebel, quien no cree que pueda suponerse que durante la Edad Media los jueces fueran conscientes de los aspectos constitucionales de sus actividades. Ello no obstante, Goebel admite que el período medieval se caracterizó por una serie de ideas dominantes, y entre ellas se hallaba la de "supremacy of the law". GOEBEL, Jr., Julius: "Constitutional History and Constitutional Law", en Columbia Law Review (Colum. L. Rev.), Vol. XXXVIII, 1938, pp. 555 y ss.; en concreeto, p. 560.

${ }^{123}$ GOUGH, J. W.: Fundamental Law in English Constitutional History, Oxford at the Clarendon Press, reprinted, Oxford, 1961, p. 65.

${ }^{124}$ HOLT, J. C.: Magna Carta, Cambridge University Press, Cambridge (Great Britain), 1992, p. 75.

${ }^{125}$ Apud Gough, J. W.: Fundamental Law in English..., op. cit., p. 15.
} 
En definitiva, en el Derecho medieval, y también lo corroboraría Gierke, todo acto del soberano que trasvasara los límites diseñados por el natural law era formalmente nulo y sin efecto. Parecen existir suficientes evidencias acerca del asentimiento que hacia tal apreciación habrían mostrado los primeros juristas británicos. Particular relevancia tiene el punto de vista de Holdsworth, quien admitiría que aunque los juristas ingleses de la Edad Media reconocían que el Parlamento era la suprema autoridad legislativa del Estado ("the supreme law-making authority"), negaban que tal autoridad equivaliera a la omnipotencia legislativa, pues no sólo la ley aprobada por el Parlamento era tan sólo una entre las diversas clases de Derecho que entonces se admitían, sino que tales juristas "habrían negado, por ejemplo, la facultad del Parlamento para aprobar una ley que contraviniera aquellas fundamental moral rules que parecían ser una parte de ese law of nature que la natural reason enseña a toda la humanidad"126. Y como antes se dijo, se admite de modo generalizado que esta creencia de los juristas ingleses medievales fue compartida por los juristas de los siglos XVI y XVII.

John Fortescue, al que ya nos hemos referido, en su De Laudibus Legum Angliae (1471), iba a desempeñar un importante rol en lo que ahora importa, al retrotraer el Derecho de Inglaterra a costumbres antiquísimas, anteriores incluso a la época romana. Al menos desde el momento de la publicación de esta obra, los juristas ingleses intentaron buscar el elemento de legitimidad del Derecho "not to reason and the knowledge of universals, but to antiquity and usage" ${ }^{127}$. Como es bastante evidente, este planteamiento conducía a considerar el common law mejor Derecho que el de ninguna otra nación, pues era el Derecho más antiguo. La idea de the ancient constitution, que para Pocock ${ }^{128}$ entrañaba originalmente una apelación a la fuerza vinculante de las antiguas costumbres y una creencia en la condición inmemorial del Derecho y la Constitución, fundada en una concepción demasiado privativa del common law y de su dogma de que el Derecho era costumbre y la costumbre, inmemorial, alcanzaría una enorme popularidad en Inglaterra a principios del siglo XVII, y se admite por la doctrina científica, que Edward Coke retomó esta doctrina, dándole su más satisfactoria formulación. "Coke's major contribution to the political and historical development of law ---

\footnotetext{
${ }^{126}$ Cit. por J. W. GOUGH: Fundamental Law in English..., op. cit., p. 45.

127 JONES, David Martin: "Sir Edward Coke and the Interpretation of Lawful Allegiance in SeventeenthCentury England", en Law, Liberty, and Parliament, Selected Essays..., op. cit., pp. 86 y ss.; en concreto, p. 88.

POCOCK, J. G. A.: La Ancient Constitution y el Derecho feudal, Editorial Tecnos, Madrid, 2011, p. 250. En el pensamiento del siglo XVIII, según este autor, ya esta idea había perdido claramente mucho de su carácter original.
} 
ha escrito Lewis ${ }^{129}$--- lay in his insistence upon preserving the medieval idea of the supremacy of law during an age when political speculation was tending to assert the necessity of the supremacy of a sovereign person or body, which was above the law". El "mito de la antigua constitución" alcanzó en el siglo XVII su punto álgido, más aún, un claro sentido prescriptivo $^{130}$. Sin ir más lejos, en 1642, el Parlamento apoyó su resistencia frente al Rey Carlos I justamente en "the ancient constitution".

Por supuesto, en el pensamiento jurídico británico no iban a faltar quienes, como Thomas Smith, iban a anteponer el poder regio a cualquier otra consideración. Aunque Smith, que fue "Regius Professor" de Derecho romano en Cambridge durante el reinado de Enrique VIII, procuró en su obra más conocida, De Republica Anglorum (1583), evitar entrar en la relación entre el Derecho positivo y el natural law, omitiendo asimismo abordar los orígenes y el desarrollo del common law y su relación con el Derecho positivo, en un momento dado iba a escribir: "To be short, the prince is the life, the head, and the authority of all things that be done in the realm of England"131. No obstante haber enfatizado en su obra los poderes del Parlamento, Smith dejaba claramente expuesta su posición en el párrafo transcrito. Es bien conocido que Bodino, también en el siglo XVI, fundamentará el poder absoluto del monarca en su derecho a dar al pueblo las leyes sin su consentimiento ("the main point of sovereign majesty and absolute power ---escribe Bodino en su clásica obra On Sovereignty--- consists of giving the law to subjects in general without their consent"). A su entender, nadie podía por tanto resistir los mandatos del soberano, por ilegales que los mismos pudieran considerarse desde la óptica de un fundamental law. Innecesario es decir, que el Rey Jacobo I compartiría en plenitud esta doctrina.

II. Muy particular relevancia ha de atribuirse en el siglo XVI a Christopher St. Germain, quien en 1523 iba a publicar una conocidísima obra llamada a ejercer una notable influencia en el pensamiento jurídico inglés del siglo XVII. Nos referimos a sus Dialogues in English between a Doctor of Divinity and a Student in the Laws of England, comúnmente

\footnotetext{
${ }^{129}$ LEWIS, John Underwood: "'Sir Edward Coke (1552-1634): His Theory of <Artificial Reason> as a Context for Modern Basic Legal Theory”, en Law, Liberty, and Parliament. Selected Essays..., op. cit., pp. 107 y ss.; en concreto, p. 111.

130 " $(\mathrm{T})$ he word constitution ---ha escrito Holt--- acquired this new prescriptive sense in the course of the seventeenth century". HOLT, J. C.: "The Ancient Constitution in Medieval England", en The Roots of Liberty, op. cit., pp. 22 y ss.; en concreto, p. 23.

${ }^{131}$ Apud BERMAN, Harold J.: "The Origins of Historical Jurisprudence...", op. cit., p. 1660.
} 
llamada Doctor and Student. En ella, nos dice Gough ${ }^{132}$, el concepto de reason ocupó el lugar del de law of nature entre los juristas ingleses de su día. Esta publicación iba a venir a probar, que en los siglos XVI y XVII, incluso antes, en la misma Edad Media, una noción acerca de la jerarquía del Derecho no era completamente desconocida para los abogados y juristas ingleses ${ }^{133}$. Por lo demás, la obra contiene algunas de las semillas que posteriormente fructificarán y se desarrollarán en la teoría jurídica inglesa ${ }^{134}$, y ello no obstante mantenerse dentro de la tradición de la filosofía jurídica europea del siglo XVI, que ya comenzaba a separarse de la teología católica-romana y del método escolástico; y así, aunque St. Germain reiterará algunas teorías de corte tomista, también se situará en otros aspectos en la línea del teólogo y filósofo francés Jean Gerson (1363-1429), seguidor de las innovadoras, y en su época muy controvertidas, teorías del franciscano Guillermo de Ockham (1290-1349).

En este diálogo, St. Germain imaginaba una conversación entre un doctor en Teología y un estudiante del common law. El autor mostraba una versión de la jerarquía medieval convencional del Derecho de Inglaterra en la que separaba seis partes. La primera era la ley de la razón, lo que mostraba lo que se acaba de decir, que el concepto de reason pasaba a ocupar el lugar de la law of nature entre los juristas ingleses de la época en que escribe St. Germain. A esa law of reason iba a atribuirle el autor la más alta autoridad, como muestran estas reflexiones:

"It ought to be kept as well among Jews and Gentiles as among Christian men.... And it is written in the heart of every man, teaching him what is to be done and what is to be fled. And because it is written in the heart, therefore it may not be put away,.... and therefore against this law, prescription, statute nor custom may not prevail. And if any be brought against it, they be no prescriptions, statutes, nor customs, but things void and against justice" ${ }^{\text {"135. (Debe }}$ mantenerse lo mismo entre los judíos y los gentiles que entre los cristianos.... Y está escrita en el corazón de cada hombre, enseñándole lo que debe de hacerse y lo que debe evitarse. Y porque está escrita en el corazón, por lo mismo no puede apartarse,.... y por consiguiente, contra esta ley, no pueden prevalecer prescripciones, estatutos ni costumbres. Y si alguna se formulara contra ella, no habrán de ser

\footnotetext{
${ }^{132}$ GOUGH, J. W.: Fundamental Law in English..., op. cit., p. 17.

${ }^{133}$ HAMBURGER, Philip: "Law and Judicial Duty", en George Washington Law Review (Geo. Wash. L. Rev.), Vol. 72, 2003-2004, pp. 1 y ss.; en concreto, p. 9.

${ }^{134}$ BERMAN, Harold J.: "The Origins of Historical Jurisprudence...”, op. cit., p. 1659.

${ }^{135}$ Apud GOUGH, J. W.: Fundamental Law in English..., op. cit., p. 18.
} 
prescripciones, estatutos ni costumbres, sino cosas nulas y contra la justicia).

Del párrafo transcrito creemos especialmente destacable el hecho de que para St. Germain la ley superior determinaba si una inferior era legítima, y si había un conflicto entre ellas, la inferior era nula. También es de reseñar el preponderante lugar que otorga a la razón en el Derecho inglés. Con base en todo ello, algunos comentaristas modernos iban a ver en estas ideas una base para que los jueces revisaran la conformidad de la legislación respecto de ese law of reason, traslación como antes se dijo de la law of nature. Los escritores de la época anterior a Coke parecían contemplar como perfectamente factible esta posibilidad, aun cuando, en el caso de St. Germain, éste no parezca visualizarla con un especial entusiasmo.

Coke mencionará Doctor and Student como fuente de autoridad, conjuntamente con Bracton y Fortescue, en un determinado pasaje del relevante Calvin's Case (1608), inmediatamente después de afirmar que el "jus naturale est, quod apud omnes homines eandem habet potentiam" "136 (la law of nature es la que tiene el mismo poder entre todos los hombres), para añadir de inmediato: "And the reason hereof is, for that God and Nature is one to all, and therefore the Law of God and Nature is one to all". De esta clara referencia a los Dialogues podría inferirse, según Berger ${ }^{137}$, que Coke iba a emplear el concepto de reason como equivalente al de law of nature, pues como antes se dijo, la law of reason iba acupar en el texto de St. Germain el lugar del law of nature. De esta forma, podía perfectamente asumirse en esa época que un estatuto "against reason" equivalía a "against the law of nature".

Si se tiene presente la tendencia del Derecho medieval que acabamos de exponer, que, insistimos, llega hasta el siglo XVII, se puede entender que Coke se sintiera identificado con esa creencia de que los tribunales podían derribar aquellos estatutos que juzgaran ofensivos de ese fundamental law de arraigo medieval, lo que era tanto como decir que los jueces, con su saber jurídico y profesionalidad, los consideraran contrarios a la razón. La referencia a St. Germain hecha por nuestro Chief Justice dos años antes del Bonham's case es un punto de apoyo adicional, que no creemos deba relativizarse por el hecho de que tal referencia no se encuentre en Bonham. La primacía con que Coke contemplará a los jueces, en

\footnotetext{
${ }^{136}$ Apud The Selected Writings and Speeches of Sir Edward Coke, op. cit., Vol. One, p. 196.

${ }^{137}$ BERGER, Raoul: “Doctor Bonham's Case: Statutory Construction...”, op. cit., p. 529.
} 
cuanto que ellos se presentaban como el arquetipo de la "artificial reason", y sus decisiones jurídicas eran probablemente mucho más lógicas, profundas y razonadas que los textos promulgados por las legislaturas, no será sino un argumento adicional a todo lo expuesto, y así puede comprenderse que existan autores, como Boyer, que consideren que, en el Bonham's case, Coke no necesitaba ninguna teoría de Dereecho natural, sino tan sólo visualizar que las decisiones judiciales "are more likely to be considered in greater depth, subtler and more flexible in responding to the facts of individual casaes and crafted with greater professional skill" 138 .

\section{B) La posición proclive a ver en el pasaje de Coke una máxima de la} interpretación estatutaria.

I. En 1938, Thorne escribía un breve, pero enjundioso artículo, en el que iba a rebatir la interpretación de Plucknett, al entender, que con su famoso pasaje Coke no pretendía tanto llevar a cabo una revisión judicial de la legislación aplicable cuanto establecer un simple canon de la interpretación estatutaria. A partir de ese momento se iba a abrir un debate que llega hasta nuestros días y sobre el que se han vertido ríos de tinta. Por razones obvias, no podemos ocuparnos aquí del mismo más que en forma extremadamente sintética.

En su análisis de la sentencia, Thorne considera que el cuarto argumento no se dirige a poner de relieve la separación de las dos cláusulas del estatuto tantas veces referidas y, de resultas de la misma, la imposibilidad de sancionar con la privación de libertad a quien ejerciera ilícitamente la práctica médica. Para este autor, el argumento bien podría entenderse así $^{139}$ : De igual modo que es absurdo interpretar el estatuto de modo tal que permita sancionar a un médico que actúa durante un mes sin licencia con una multa de 100 chelines, y castigarle después con prisión por la única falta de empeñarse en la práctica no autorizada de la medicina, esto es, castigarle dos veces por la misma falta, es asimismo absurdo interpretarlo en el sentido de que permita al College ser juez y parte en un proceso, en cuanto que puede imponer multas de las que una parte de su cuantía pasan a su pecunio. Aunque el estatuto otorga al Colegio la facultad de multar a los médicos que practican la medicina sin la pertinente licencia, cuando se constata que el College tiene un interés directo de carácter

\footnotetext{
${ }^{138}$ BOYER, Allen Dillard: “<Understanding, Authority, and Will>...”, op. cit., p. 91.

${ }^{139}$ THORNE, S. E.: "Dr. Bonham's Case”, op. cit., p. 548.
} 
pecuniario en la imposición de esas multas, y por lo mismo en la causa, sería imposible sin incurrir en un absurdo adherirse a términos tan inequívocos. Por lo tanto, el College no puede multar. De esta forma, la multa impuesta a Thomas Bonham no estaba legalmente impuesta y, por lo tanto, la prisión que la acompañaba se hallaba injustificada.

Así visualizado, para Thorne, el cuarto argumento del Chief Justice está lejos de ser un dictum, presentándose por el contrario como una verdadera parte material de su razonamiento. Dicho de otro modo, el pasaje de Coke no sería un mero obiter dictum sino una parte integral de la argumentación encaminada a mostrar que, de conformidad con una interpretación adecuada de las cartas patente y del estatuto que las confirmaba, el Colegio de Médicos no poseía la facultad que pretendía. Y aunque este argumento está expresado en términos muy amplios, no visualiza la nulidad del estatuto a causa de un conflicto entre éste y el common law, natural law o higher law, sino simplemente el rechazo a seguir un estatuto absurdo a simple vista. Así entendido, Coke se estaba limitando a sentar un criterio hermenéutico de aplicación al Derecho estatutario.

El Profesor de la "Northwestern University" refuerza su tesis acudiendo a la interpretación del término "repugnancy" (lo que se justifica por la frase de la sentencia "repugnant or impossible to be performed"), del que recuerda que era muy familiar a los abogados del siglo XVII. Una "repugnancy" es una contradicción; ocurre cuando un estatuto dispone una cosa y después, quizá por descuido, lo opuesto. Cuando nos enfrentamos a un estatuto contradictorio ("a repugnant statute"), tenemos primeramente que interpretarlo de modo tal que evitemos sus palabras (los términos contradictorio como es obvio), pero si eso es imposible, entonces nuestro autor se decanta por considerar buenas las primeras palabras, debiendo por el contrario omitirse las últimas, en cuanto que son éstas las que generan una colisión por razón de su contradicción. Enfrentado a disposiciones contradictorias, un tribunal debe evitar en la medida de lo posible la colisión antes que dejar caer el estatuto, y de ahí Thorne infiere su conclusión de que "there is no conscious constitutional problem raised here, but only one of statutory construction. We are looking at a statute from the point of view of a judge called upon to apply it in a particular case. Since a provision and its opposite cannot both be applied, the later contradictory words are regarded as of no effect ${ }^{\prime 140}$.

\footnotetext{
${ }^{140}$ Ibidem, p. 549.
} 
Proyectando su reflexión al Bonham's case, Thorne cree que aunque no sea técnicamente una contradicción ("a repugnancy"), desde luego, un estatuto que hace a un hombre juez de su propio caso puede equipararse a un estatuto contradictorio, y que si no obstante esta circunstancia Coke hizo tomar forma a su doctrina de un estatuto contrario al common right and reason, fue por razón de los precedentes a los que aludió en la sentencia, no con base en ninguna teoría de Derecho natural, al margen ya de considerar que el cuarto argumento se expresa en el lenguaje de la interpretación legal ${ }^{141}$.

II. Diversas posiciones doctrinales más próximas en el tiempo parecen inclinarse por la tesis de Thorne, aunque la cuestión, como ya se ha dicho, está lejos de ser pacífica entre la doctrina. Entre la doctrina norteamericana reciente, Kramer, en un artículo bien conocido, sigue de cerca esta dirección. Para el Profesor de la "New York University" "142, los esfuerzos de Coke se dirigieron no a establecer un control judicial respecto de un fundamental law, sino más bien a limitar el poder del Rey frente al Parlamento. Con su dictum, Coke estaba proponiendo una regla de interpretación legal de conformidad con la cual, una ley que contradijera principios jurídicos establecidos debía interpretarse estrictamente, en ausencia de una clara declaración para lo contrario.

En una línea no muy distante se sitúa MacKay, quien cree que aunque a primera vista el pasaje de Coke parece una afirmación directa de la existencia de un poder muy superior ("a much greater power") en el common law, sin embargo, desde el punto de vista existente en el siglo XVII, el control ejercido por el common law sobre el Derecho estatutario puede ser fácilmente explicado como interpretación ${ }^{143}$. Ahora bien, MacKay efectua una matización importante, al entender que Coke no pretende justificar con su pasaje la existencia de unos amplios poderes de interpretación para los tribunales, pues la única razón para la existencia de

\footnotetext{
${ }^{141}$ Thorne argumenta asimismo (en Ibidem, p. 550), que dos años después del caso que nos ocupa, en Rowles v. Mason (1612), Coke se dio cuenta de que common right and reason y repugnancy eran aproximadamente equivalentes. Pero en realidad, un amplio sector de la doctrina vincula estrechamente el Rowles case con el Bonham's case; así, para MacKay, el Rowles case ilustra acerca de cómo la idea de supremacía del common law parece haber quedado adherida en la mente de Coke. (MacKAY, R. A.: "Coke—Parliamentary Sovereignty...", op. cit., p. 226). Y en efecto, en Rowles, Coke declaraba que el common law "corrects, allows, and disallows, both statute law, and custom, for if there be repugnancy in statute; or unreasonableness in custom, the common law disallowes and rejects it, as appears by Doctor Bonham's Case". (Apud CORWIN, Edward S.: "The <Higher Law> Background of American Constitutional Law" (II), op. cit., p. 374).

${ }_{142}$ KRAMER, Larry D.: "We the Court" (The Supreme Court 2000 Term. Foreword), en Harvard Law Review (Harv. L. Rev.), Vol. 115, 2001-2002, pp. 5 y ss.; en concreto, p. 25.

${ }^{143}$ MacKAY, R. A.: “Coke-Parliamentary Sovereignty or the Supremacy of the Law?”, op. cit., pp. 222-223.
} 
esta facultad es la de poner los estatutos en conformidad general con el fundamental law, que no obstante ser un término algo vago, representa la razón general y la justicia del Derecho, antes que un cuerpo normativo definido ${ }^{144}$.

Algunos sectores de la doctrina, aún siguiendo en lo básico la línea interpretativa precedente, han establecido determinadas matizaciones. Stoner ha dedicado una gran atención al tema ${ }^{145}$, y aunque se decanta por la tesis interpretativista, por así llamarla, mantiene una posición que introduce un notable matiz. Para este autor, la celebrada declaración del Bonham's case, por la lógica del argumento global, encaja en un acto judicial de interpretar, no de derribar, un estatuto ("a judicial act of interpreting, not striking down, a statute"), y el principio que invoca impregna el caso como un todo; sin embargo, es difícil negar que la modestia de la forma judicial contradiga algo su más amplio significado ${ }^{146}$. A Coke, como ya señalamos, le gustaba decir que la Carta Magna era como Alejandro Magno, magnum in parvo, esto es, una gran cosa en una pequeña forma, y Stoner se muestra tentado de aplicar su adagio a las propias palabras pronunciadas en el Bonham's case. Coke estaría interpretando el estatuto, pero la máxima jurídica en nombre de la cual lo estaría haciendo no sería un mero tecnicismo sino un gran principio, como el de que ningún hombre debe ser juez en su propia causa, que en último término estaría encarnando un higher law.

También Gray (que revela en su trabajo haber encontrado entre los manuscritos del British Museum algún material nuevo sobre el caso, destacando un manuscrito que, confrontado con las fuentes impresas, era capaz de afectar al significado fundamental del mismo) establece matices de interés. A su juicio ${ }^{147}$, cuando Coke actuó como un juez, decidiendo sobre el caso, por ningún medio defendió la doctrina de la judicial review, ni excedió los límites de la interpretación jurídica. Dicho de otro modo, como presidente del Tribunal, Coke se limitó en su famoso pasaje a sentar un criterio hermenéutico; Coke tenía en mente una interpretación estricta para evitar un resultado desafortunado. Sin embargo, como redactor del informe sobre el propio caso, Coke iba a mejorar su propia sentencia. "Coke as reporter, ---escribe Gray--- reporting his own opinion <improved> it in such a way as at least to suggest that he wanted to make claims for something like judicial review". Al preparar el texto del caso para su impresión, reflexionando acerca del relevante poder y trascendencia del

\footnotetext{
${ }^{144}$ Ibidem, p. 230.

145 STONER, James R.: Common Law and Liberal Theory..., op. cit., pp. 52-62.

146 Ibidem, p. 59.

${ }^{147}$ GRAY, Charles M.: "Bonham's Case Reviewed", op. cit., p. 36.
} 
common law, Coke quiso mostrar lo máximo ("the most") que podía hacerse a la vista de las “autoridades", esto es, de los precedentes, en que él había tratado de fundamentar su pasaje. Y decidió que tales precedentes o "autoridades" podían efectivamente apoyar una doctrina de judicial review, aunque Coke no hubiera pensado en las consecuencias de la misma ${ }^{148}$. El propio autor, al analizar las reacciones que en su tiempo desencadenó el famoso dictum, cree que hay evidencias que sugieren que la plasmación del mismo en sus Reports se entendió por sus contemporáneos como "a true judicial review position" 149.

\section{C) La posición tendente a ver en el dictum la enunciación de la teoría} constitucional de la judicial review.

La posición doctrinal mayoritaria, no nos cabe duda de ello, sigue siendo la marcada tiempo atrás por Plucknett, esto es, la que, con unos u otros matices, ve en el dictum de Coke la enunciación de la teoría constitucional de la judicial review. A partir de ello, no faltan ciertas precisiones, ni tan siquiera posiciones más exóticas, por así llamarlas, como la de quien, una vez admitida la paternidad de Coke en lo que se refiere a la judicial review, procede de inmediato a descalificarla. Paradigmática es al respecto la posición del siempre polémico Crosskey, quien tras admitir que el origen de la idea de la judicial review parece remontarse más que probablemente al Bonham's case, tilda de inmediato la idea de Coke como una "ill-founded idea"150.

Roscoe Pound, el gran Decano de Harvard, como ya tuvimos oportunidad de señalar, no pareció albergar dudas acerca de que el dictum de Coke parece ser la primera exposición acogida en sus Reports de la teoría de la inaplicación de una ley por su vulneración del natural law, o lo que es igual, del common right and reason ${ }^{151}$. Y un profundo conocedor del pensamiento de Coke como es Allen Boyer, no duda en afirmar que la doctrina moderna de la judicial review localiza sus orígenes en la sentencia dictada por Coke en el Bonham's case ${ }^{152}$. Coke, añade en otro momento Boyer ${ }^{153}$, actuó en la creencia de que los tribunales podían

\footnotetext{
148 Ibidem, p. 49.

149 Ibidem, p. 36.

150 CROSSKEY, William Winslow: Politics and the Constitution in the History of the United States, The University of Chicago Press, Chicago, 1953, Vol. II, p. 941.

${ }^{151}$ POUND, Roscoe: "Common law and legislation", op. cit., p. 391.

152 BOYER, Allen Dillard: <Understanding, Authority, and Will>...”, op. cit., p. 45.

${ }^{153}$ Ibidem, p. 85.
} 
derribar los estatutos que contrariaran el common law, o lo que es igual, aquellas normas que, con su saber, consideraran unreasonable.

Ha sido Berger quien de modo más elaborado ha defendido la tesis proclive a ver en el pasaje de Coke la formulación de la doctrina de la anulación judicial de los estatutos que violaran el higher law ${ }^{154}$. Para Berger, describir el pasaje de Coke como un "canon of statutory construction" de ningún modo agota sus consecuencias; permanece su afirmación de que una ley que haga a una parte juez de su propia causa es contraria al common law and reason y por lo tanto nula. Esta afirmación no está desprovista de un significado “constitucional" porque haya sido emitida en un proceso de "interpretación"155. Es cierto, admite Berger, que si nos empeñáramos en forjar una "teoría constitucional", estaríamos atribuyendo a Coke un hasta ahora inimaginable intento de conceptualización, pero, con todo, la vinculación de la etiqueta "interpretación" ("construction") al concepto germinal no comporta que el problema constitucional desaparezca.

En fin, Berger entiende ${ }^{156}$, y no le falta razón, que es inútil pensar que uno pueda asignar a las palabras formuladas por Coke hace cuatro siglos un significado definitivo. Los comentarios llevados a cabo por la doctrina de nuestro tiempo sobre las palabras de Coke le parecen a Berger ingeniosos y debatibles, y a la vista de ello él opta por el riesgo de ser simplista, interpretando "against reason" como se hizo por St. Germain en Doctor and Student, esto es, como algo prohibido por el Derecho natural ("the law of nature").

Otras posiciones doctrinales, con unos u otros argumentos, son reconducibles a la teoría constitucional. Es el caso de Thomas Grey ${ }^{157}$, para quien los términos de Coke en el litigio que nos ocupa, indudablemente, reclaman para los tribunales ordinarios la facultad de hacer caso omiso del claro significado de los estatutos cuando colisionen con el common law and reason. Los estatutos que violen ese common law and reason son completamente nulos ("utterly void") y, según este autor, estos no son términos usuales en la interpretación estatutaria. De modo similar, McGovney cree ${ }^{158}$, que el germen remoto del pensamiento que

\footnotetext{
154 BERGER, Raoul: "Dr. Bonham's Case". Appendix A, inserto en la obra del propio autor, Congress v. the Supreme Court, Harvard University Press, Cambridge, Massachusetts, $2^{\text {nd }}$ printing, 1974, pp. 349 y ss.

155 Ibidem, p. 350.

156 Ibidem, p. 368.

157 GREY, Thomas C.: "Origins of the Unwritten Constitution: Fundamental Law in American Revolutionary Thought”, en Stanford Law Review (Stan. L. Rev.), Vol. 30, 1977-1978, pp. 843 y ss.; en concreto, p. 856.

158 McGOVNEY, Dudley Odell: "The British Origin of Judicial Review of Legislation", en University of Pennsylvania Law Review (U. Pa. L. Rev.), Vol. 93, 1944-1945, pp. 1 y ss.; en concreto, pp. 1-2. Coke, añade
} 
evolucionó en la judicial review of legislation fue traido al mundo por Sir Edward Coke con ocasión de su sentencia en el Bonham's case. Tomado literalmente, el pasaje asume que el Parlamento no es una legislatura ilimitada, pues carece de facultad para promulgar un estatuto contrario a los principios del common law. En similar la dirección, Bowen, biógrafa de Coke, sostiene $^{159}$, que Coke aprovechó la ocasión que le dio el Bonham's case para declarar que el common law se hallaba por encima del Parlamento lo mismo que del Rey. Black ha mostrado su disconformidad con quienes piensan que Coke no estaba afirmando con su dictum un deber del tribunal de declarar las leyes nulas, recomendando a quienes así lo crean que vuelvan a las, al parecer, nunca leídas últimas páginas de su Report del caso, en las que establece con cuidado el procedimiento a seguir en el futuro por el Colegio de Médicos, páginas que, según la autora ${ }^{160}$, podrían encabezarse con el rótulo de "Rules for Avoiding Being a Judge in your own Cause and Other Wise Precautions". En fin, para Smith ${ }^{161}$, con este pasaje Coke estaba sustentando la idea de que los tribunales permanecían por encima de todos los demás cuerpos como protectores y encargados de hacer cumplir el fundamental law ("as the protector and enforcer of the fundamental law"). La idea de Coke de un Derecho natural superior al Derecho elaborado por el hombre no era especialmente novedosa; lo que a la par resultaba nuevo y radical era que a los tribunales les fuera dada la facultad y el derecho de velar por el cumplimiento de esa superioridad del fundamental law. En eso justamente reside la peculiar contribución de Coke a la judicial review. De esta forma, concluye el mencionado autor, el célebre dictum se convirtió en la fuente más importante del concepto de judicial review.

Terminaremos recordando la posición de Edward Corwin, sin género alguno de duda, el más cualificado estudioso norteamericano del instituto de la judicial review of legislation, de cuya posición ya nos hemos hecho eco, por lo que tan sólo diremos que Corwin entiende como algo seguro ${ }^{162}$, que con su dictum Coke no estaba afirmando una simple regla de interpretación estatutaria que debiera su fuerza a la supuesta intención del Parlamento, aunque el estatuto implicado en el Bonham's case fuera también interpretado desde ese punto de

más adelante McGovney, "had set an idea loose in the world, the idea that there was a higher law limiting legislatures and that courts in their ordinary administration of justice between man and man had power to give judgment according to that higher law in disregard of any legislative act inconsistent with it" (Ibidem, p. 3).

${ }^{159}$ Catherine Drinker BOWEN: The Lion and the Throne (The Life and Times of Sir Edward Coke. 1552-1634), Hamish Hamilton, London, 1957, pp. 271-272.

160 BLACK, Barbara A.: "The Constitution of Empire: The Case for the Colonists", en University of Pennsylvania Law Review (U. Pa. L. Rev.), Vol. 124, 1975-1976, pp. 1157 y ss.; en concreto, p. 1208.

${ }_{161}$ SMITH, II', George P.: "Dr. Bonham's Case and the Modern Significance...", op. cit., pp. 310 y 313.

162 CORWIN, Edward S.: "The <Higher Law> Background of American Constitutional Law" (II), op. cit., p. 372 . 
vista. Más allá de ello, el Chief Justice estaba dando fuerza a una norma de Derecho superior (higher law) que él consideraba vinculante no sólo para el Parlamento, sino también para los tribunales ordinarios. No en vano la expresión common right and reason podía perfectamente equipararse a algo fundamental, a algo permanente, en definitiva, a un higher law, como por lo demás vendría a corroborar la teoría constitucional americana, que vería fáciles de encontrar tales axiomas en el propio Digesto y en el Código de Justiniano.

\section{D) Algunas reflexiones finales propias en defensa de la teoría constitucional.}

I. Aunque creemos que a lo largo de estas páginas ya hemos tenido la oportunidad de mostrar nuestro punto de vista acerca del sentido del dictum de Coke, creemos necesario ahora efectuar unas reflexiones finales que compendien nuestra posición, no sin añadir alguna reflexión adicional. Digamos ante todo que es bastante dificultoso, si es que no por entero imposible, extraer un juicio absolutamente concluyente de lo que Coke quiso expresar en su célebre pasaje. Los argumentos de Thorne no dejan de encerrar una notable carga de convicción. Pero incluso aunque admitiéramos que en el célebre pasaje late un principio de interpretación estricta atribuible a los tribunales de la época en orden a evitar las contradicciones y absurdos a que pudiera conducir un determinado texto estatutario y a conformar la norma estatutaria a esa idea de la justicia y razonabilidad general del Derecho tan arraigada en la época, quedarnos en el mero principio hermenéutico creemos que resultaría por entero insuficiente. Así lo han admitido incluso algunos autores que han hecho prevalecer la tesis interpretativista.

Y es que la etiqueta que circunscribe el pasaje a una máxima de la interpretación estatutaria difícilmente puede cerrar el tema, incluso si pensáramos que Coke pudo tenerla presente. La regla nemo iudex in propria causa encarnaba un principio superior, incardinable en un higher law, y ello, inexcusablemente, debe ser tomado en cuenta, pues Coke no estaba expresando una regla hermenéutica cuya razón de ser fuera salvaguardar la supuesta intención del Parlamento, sino más bien proteger algo fundamental, que vinculaba al propio Parlamento. E innecesario es decir que la propia dicción del pasaje parece estar reclamando de los tribunales algo que va más allá de una estricta interpretación estatutaria.

Si dejamos de lado el caso propiamente dicho y atendemos a otros factores que podríamos llamar contextuales, la impresión de que Coke estaba expresando una teoría 
constitucional se acrecienta. La tradición medieval a la que nos hemos referido con algún detalle creemos que es incontrovertible en lo que se refiere al reconocimiento de la primacía de un fundamental law. Como ya expusimos, en el Derecho medieval, todo acto del soberano que trasvasara los límites diseñados por el natural law, verdadero fundamental law, era formalmente nulo y sin efecto. No vamos a volver a hacernos eco de las numerosas muestras que de ello hemos aportado. Si recordamos de modo específico la obra Doctor and Student, mencionada por Coke como fuente de autoridad en el Calvin's case, tan sólo dos años antes del Bonham's case, podemos pensar que Coke estaba equiparando reason (o law of reason) con law of nature, lo que tampoco había de ponerse en exclusiva conexión con la obra de St. Germain, por cuanto, como ya se ha dicho, el concepto de reason iba a ocupar entre los juristas ingleses de la época el lugar del law of nature. En cualquier caso, para St. Germain era claro que la law of reason era la fuente jurídica superior y cualquier fuente inferior en contradicción con ella había de considerarse nula.

II. Si atendemos a su vez al entendimiento que del dictum se tuvo en la época nos encontramos con datos bien significativos. En el período en que se enmarca la vida pública de Coke, el Parlamento era un órgano supremo en cuanto órgano jurisdiccional, no habiendo sin embargo alcanzado aún su superioridad en su calidad de órgano legislativo. Su supremacía como tribunal de última instancia, frente al que no había apelación posible, le otorgaba competencia para revisar y cambiar cualquier norma estatutaria o cualquier principio del common law. Ello nos puede hacer comprender, que en esta época lo que se cuestionaba no era tanto si los tribunales tenían la facultad de declarar nula, en parte o en su totalidad, una ley del Parlamento, sino más bíen qué tribunales disponían de tal facultad. Esta perspectiva aparece claramente puesta de relieve en la alocución hecha por Lord Ellesmere con ocasión de la prestación de su juramento del cargo de presidente del King's Bench por Sin Henry Montague, que sucedió en dicho cargo a Edward Coke, una vez que éste fue cesado por el Rey. En sus palabras, Lord Ellesmere, uno de los grandes enemigos de Coke, como ya dijimos, recordaba a Montague la figura de su abuelo, un antiguo Chief Justice de la Court of Common Pleas:

"He ---decía Ellesmere--- questioned not power for the Judges of this Court to correct all misdemeanors as well extrajudicial 
as judicial, not to have power to judge Statutes and Acts of Parliament to be void, if they conceived them to be against common right and reason; but he left the King and the Parliament to judge what was common right and reason. I speak not of impossibilities or direct repugnances" ${ }^{\prime 163}$. (Él no puso en duda la facultad de los jueces de este Tribunal para corregir todas las faltas tanto extrajudiciales como judiciales, ni para tener la facultad de decidir que los estatutos y leyesdel Parlamento son nulos, si éste los concibiera contrarios al common right and reason, pero dejó al Rey y al Parlamentodecidir lo que era common right and reason. Yo no hablo de imposibles o de contradicciones directas).

Esta declaración entrañaba una nada solapada crítica a Coke, antecesor en el cargo de Montague, y a la par suponía una suerte de advertencia al nuevo presidente para que actuara de otro modo. Si al margen ya de algún otro supuesto, como el de la contradicción, la colisión de un estatuto con el common law and reason podía entrañar su nulidad, pero sólo al Rey y al Parlamento correspondía decidir lo que era common right and reason, parecía claro que tal declaración de nulidad podía hacerse, pero sólo por el Rey y el Parlamento, éste en su condición de High Court. Dicho de otro modo, Lord Ellesmere no estaba cuestionando que se pudiera derribar un estatuto por contradecir un Derecho superior; lo que cuestionaba es que lo pudiera hacer un tribunal distinto del Parlamento, que al fin y a la postre era el órgano jurisdiccional supremo. La objeción del Lord Chancellor a la doctrina de Coke, que ha llegado a ser equiparada a la que el Juez Gibson expresara (en su célebre dissenting opinion formulada en el caso Eakin v. Raub) frente a la doctrina fijada por Marshall en Marbury $v$. Madison, da una visión de la problemática en cuestión harto diferente.

Las críticas de Lord Ellesmere se reiterarían en similar dirección en otras diversas oportunidades. Así, refiriéndose al Bonham's case, tal y como era recogido en los Reports de Coke, Ellesmere, en el Earl of Oxford Case (1615), argumentaba del siguiente modo:

"It seemeth, by the Lord Coke's report.... in Dr. Bonham's Case, That Statutes are not so sacred as that the Equity of them may not be examined. For he saith, That in many Cases the Common Law hath such a Prerogative, as that it can controul Acts of Parliament, and adjudge them void; as if they are against Common Right, or Reason, or Repugnant, or impossible to be performed.... And yet our Books are, That the Acts and Statutes of Parliament ought to be

\footnotetext{
${ }^{163}$ Apud MacKAY, R. A.: “Coke-Parliamentary Sovereignty or the Supremacy of the Law?”, op. cit., pp. 228229.
} 
reversed by Parliament (only) and not otherwise" ${ }^{\text {"164 }}$. (Pareciera por el informe de Lord Coke en el caso del Dr. Bonham, que los estatutos no son tan sagrados como para que su equidad no pueda examinarse. Pues él dice, que en muchos casos el common law tiene tal prerrogativa, como para que pueda controlar las leyes del Parlamento y juzgarlas nulas, como si son contrarias al common right, o a la razón, o contradictorias o imposibles de cumplirse. Y sin embargo, en nuestros Libros está, que las leyes y estatutos del Parlamento deben anularse ---solamente--- por el Parlamento, y no de otro modo).

A la vista de las reflexiones del Lord Canciller, es claro que lo que éste criticaba no era que Coke hubiera llevado a cabo un control de la conformidad de un estatuto con el common right and reason, por la intrínseca imposibilidad de llevar a cabo esa fiscalización, sino porque al hacerlo así había invadido una función que le era ajena. Corwin, tiempo atrás, ya puso de relieve esta misma circunstancia al escribir ${ }^{165}$, que la cuestión contemporáneamente originada por el dictum no era, como diríamos hoy, entre el poder judicial y el legislativo, sino "between the law declaring power of the ordinary courts and the like power of the High Court of Parliament". Pero en cualquier caso, Ellesmere estaba dando por supuesto que con su dictum Coke había llevado a cabo un control de la conformidad del estatuto con ese higher law. La crítica de Ellesmere no venía referida al establecimiento por el Chief Justice de una máxima de la interpretación estatutaria, sino a la realización de un control de la conformidad de un estatuto con un higher law.

III. A idéntica conclusión llegamos si valoramos las reacciones provocadas por la sentencia de Coke en los años sucesivos. A la vista de ellas, la idea de la teoría constitucional se refuerza, en detrimento de la tesis puramente hermenéutica. Bastaría con un único ejemplo para constatarlo, el que nos proporciona el caso Rouswell v. Ivory (1619), visto ante el Tribunal de la Chancillería, del que hay un específico documento en el British Museum. En él, el abogado Crewe, amigo y pariente de Coke, mencionó el Bonham's case aduciendo, que de acuerdo con el mismo los tribunales de common law podían anular ("overrule") estatutos, y que el Chancellor, del mismo modo, podía anular leyes del Parlamento ("might overrule acts

\footnotetext{
${ }^{164}$ Apud BERGER, Raoul: “Doctor Bonham's Case: Statutory Construction or Constitutional Theory?”, op. cit., p. 541.

${ }_{165}$ CORWIN, Edward S.: "The <Higher Law> Background of American Constitutional Law" (II), op. cit., pp. 373-374.
} 
of Parliament") ${ }^{166}$. Hay que suponer que una persona, también de la profesión jurídica, tan próxima a Coke conocería de primera mano lo que su pariente el Chief Justice quiso decir con su dictum.

La misma idea se entresaca de la actuación de Sir Henry Hobart, Chief Justice de la Court of Common Pleas, sucesor de Coke en el cargo, quien respaldó los puntos de vista de Coke, tomados de nuevo en su más novedoso sentido, esto es, como punto de partida de la doctrina de la judicial review. Plucknett ${ }^{167}$ no sólo no duda de ello, sino que considera a Hobart un inquebrantable defensor del punto de vista de Coke sobre el common law ("a staunch upholder of Coke's view of the common law"), de lo que constituye buena prueba el caso Day v. Savadge (1615) ${ }^{168}$. En la decisión de este último caso puede leerse: “even an Act of Parliament made against natural equity, as to make a man judge in his own cause, is void in itself, for Jura naturae sunt immutabilia and they are leges legum"169 (incluso una ley del Parlamento hecha en contra de la equidad natural, como para hacer a un hombre juez de su propia causa, es nula en sí misma, pues los derechos de la naturaleza son inmutables y son ley de leyes). De esta forma, Hobart traía en apoyo de la interpretación propia de la teoría constitucional del dictum de Coke a Henry de Bracton y, en último término, al propio Cicerón. Aquí, la alusión hecha en el Bonham's case a "against common right and reason" (que Hobart sustituye por la de "against natural equity") permanece aislada, sin verse acompañada por la referencia a la "repugnancy", y en cuanto a la inclusión de la frase latina, cabe recordar que ya Coke, aunque no en el Bonham's case, la había mencionado (en el Calvin's case), citando la obra Doctor and Student. Con su afirmación, Hobart daba un paso adelante respecto a las posiciones sustentadas por Coke, avanzando la teoría de que cualquier acto del soberano que quebrantara los límites impuestos por el Derecho natural era formalmente nulo.

\footnotetext{
${ }^{166}$ Apud BOYER, Allen Dillard: “<Understanding, Authority, and Will>...”, op. cit., p. 86, nota 153.

${ }^{167}$ PLUCKNETT, Theodore F. T.: "Bonham's Case and Judicial Review”, op. cit., p. 49.

${ }^{168}$ Los hechos del caso Day v. Savadge pueden resumirse así: Savadge, en nombre de la ciudad de Londres, demandó el pago de ciertos derechos de embarcadero a Day, quien sostuvo que de acuerdo con la costumbre de la ciudad él no estaba sujeto al pago de tales derechos. Se suscitó así la cuestión de si tal costumbre existía y cómo podía juzgarse su existencia. La ciudad adujo un antiguo privilegio que, según alegó, le había sido confirmado por un estatuto de Ricardo II, y que autorizaba a su Secretario-Archivero ("Recorder") a declarar de viva voz cuáles eran las costumbres de la ciudad, frente a lo que se objetó que tal procedimiento haría a la ciudad juez de su propia causa ("judge in their own cause").

Apud Raoul BERGER: "Dr. Bonham's Case”, op. cit., p. 364. Asimismo, en: PLUCKNETT, Theodore F. T.: "Bonham's Case and Judicial Review", op. cit., p. 49.
} 
Una confirmación adicional de tal interpretación viene ofrecida por un tratado publicado en 1627 por el abogado Sir Henry Finch, en que declara: "It is truly said, and all men must agree, that laws indeed repugnant to the law of reason are as well void as those that cross the law of nature" $" 170$.

IV. Para terminar hemos de hacernos eco de uno de los argumentos a los que con bastante frecuencia ha aludido la doctrina proclive a ver en el dictum de Coke un mero principio hermenéutico. Se trata de una reflexión hecha por el propio Coke en el cuarto de sus Institutes of the Lawes of England, en donde, al abordar el poder y jurisdicción del Parlamento, escribe:

"Of the power and jurisdiction of the Parliament for making of laws in proceeding by Bill, it is so transcendent and absolute, as it cannot be confined either for causes or persons within any bounds" (El poder y jurisdicción del Parlamento para hacer leyes, procediendo a través de proyectos de ley, es tan trascendente y absoluto que no puede confinarse ni por causas ni por personas dentro de ningún límite), tras lo que añade: "Of this Court it is truly said: $S i$ antiquitatem spectes, est vetustissima, si dignitatem, est honoratissima, si jurisdictionem, est capacissima" ${ }^{\text {171 }}$. (De este Tribunal se ha dicho fielmente, que si se considera su antigüedad, es el más antiguo, si su dignidad, es el más honorable, si su jurisdicción, es la más extensa).

En la primera parte del texto transcrito algunos han visto una contradicción con la supuesta formulación por Coke de la doctrina de la existencia de un higher law vinculante, cuya vulneración por una norma estatutaria podría desencadenar la nulidad de la misma, contradicción que podría acentuarse si se tiene en cuenta que Blackstone, algo más de un siglo después, usó en sus Commentaries on the Laws of England el mismo pasaje para expresar la contrapuesta idea de la soberanía parlamentaria. Frente a esas consideraciones, nos alineamos más bien con Corwin, quien siguiendo a McIlwain consideró ${ }^{172}$, que en las páginas de Coke el texto en cuestión no podía tener el significado que le diera Blackstone, pues como sus

\footnotetext{
${ }^{170}$ Apud BERGER, Raoul: "Dr. Bonham's Case", op. cit., p. 365.

171 "The Fourth Part of the Institutes", Chapter I ("Of the High and Most Honourable Court of Parliament"), en The Selected Writings and Speeches of Sir Edward Coke, op. cit., Vol. Two, pp. 1062 y ss.; la cita transcrita en p. 1133.

${ }^{172}$ CORWIN, Edward S.: "The <Higher Law> Background of American Constitutional Law" (II), op. cit., pp. 378-379.
} 
propias palabras indican, él clasifica el Parlamento, esencialmente ("primarily") como un tribunal, aunque sea un tribunal que tanto puede hacer nuevo Derecho como declarar el viejo, y lo que con ello está describiendo Coke no es un poder y jurisdicción que se halle facultado para dejar de lado derechos a voluntad, aunque tenga competencia para alcanzar a todas las personas y causas. Además, las ilustraciones que da del "trascendente poder y jurisdicción del Parlamento" no son, de acuerdo con los standards actuales, ejemplos de poder legislativo en absoluto, ("are not, by today's standards, instances of law-making at all") sino del ejercicio de una especie de jurisdicción de equidad en casos individuales.

También Smith considera muy dudoso que Coke vinculara el mismo significado a su afirmación que la que le habría de dar Blackstone. Coke, argumenta el citado autor ${ }^{173}$, no reconoció ni una vez la antítesis entre "adjudication" y "legislation”. Coke consideraba que las leyes que el Parlamento promulgaba eran análogas a las decisiones adoptadas por un tribunal, por lo que, consideradas como tales, no se contemplaban como normas de una naturaleza inviolable hechas por una legislatura omnipotente, sino más bien como decisiones de otro tribunal a las que siempre podía hacérseles caso omiso si contravenían el fundamental law. De esta forma, para Coke, el Parlamento era supremo con tal de que permaneciera dentro de la esfera del common law.

Poco más puede añadirse. Los argumentos expuestos (en positivo y negativo) creemos que justifican sobradamente que, aún admitiendo las dificultades a las que ya hemos hecho mención, nos decantemos por la interpretación que ve en el dictum de Coke la formulación de la doctrina de la judicial review.

\section{Bibliografía}

BAKER, J. H.: An Introduction to English Legal History, Butterworths, $2^{\text {nd }}$ edition, London, 1979.

BERGER, Raoul: "Doctor Bonham's Case: Statutory Construction or Constitutional Theory?", en University of Pennsylvania Law Review (U. Pa. L. Rev.), Vol. 117, 1968-1969, pp. 521 y ss.

\footnotetext{
${ }^{173}$ George P. SMITH, II': "Dr. Bonham's Case and the Modern Significance of Lord Coke's Influence”, op. cit., pp. 310-311.
} 
BERMAN, Harold J.: "The Origins of Historical Jurisprudence: Coke, Selden, Hale", en Yale Law Journal (Yale L. J.), Vol. 103, 1993-1994, pp. 1651 y ss.

BLACK, Barbara A.: "The Constitution of Empire: The Case for the Colonists", en University of Pennsylvania Law Review (U. Pa. L. Rev.), Vol. 124, 1975-1976, pp. 1157 y ss.

BOUDIN, Louis B.: "Lord Coke and the American Doctrine of Judicial Power", en New York University Law Review (N. Y. U. L. Rev.), Vol. 6, 1928-1929, pp. 223 y ss.

BOWEN, Catherine Drinker: The Lion and the Throne (The Life and Times of Sir Edward Coke. 1552-1634), Hamish Hamilton, London, 1957.

BOYER, Allen Dillard: "<Understanding, Authority, and Will>: Sir Edward Coke and the Elizabethan Origins of Judicial Review", en Boston College Law Review (B. C. L. Rev.), Vol. XXXIX, 1997-1998, pp. 43 y ss.

CORWIN, Edward S.: "The <Higher Law $>$ Background of American Constitutional Law" (I), en Harvard Law Review (Harv. L. Rev.), Vol. XLII, 1928-1929, pp. 149 y ss.

CROSSKEY, William Winslow: Politics and the Constitution in the History of the United States, The University of Chicago Press, Chicago, 1953, Vol. II.

DAWSON, John P.: "Coke and Ellesmere Disinterred: The Attack on the Chancery in 1616", en Illinois Law Review (Ill. L. Rev.), Vol. 36, 1941-1942, pp. 127 y ss.

GOEBEL Jr., Julius: “Constitutional History and Constitutional Law", en Columbia Law Review (Colum. L. Rev.), Vol. XXXVIII, 1938, pp. 555 y ss.

GOUGH, J. W.: Fundamental Law in English Constitutional History, Oxford at the Clarendon Press, reprinted, Oxford, 1961.

GRAY, Charles M.: "Bonham's Case Reviewed", en Proceedings of the American Philosophical Society (Proc. Amer. Phil. Soc.), Vol. 116, No. 1, February 15, 1972, pp. 35 y ss.

: "The Boundaries of the Equitable Function", en The American Journal of Legal History (Am. J. Legal Hist.), Vol. 20, 1976, pp. 192 y ss.

GREY, Thomas C.: "Origins of the Unwritten Constitution: Fundamental Law in American Revolutionary Thought", en Stanford Law Review (Stan. L. Rev.), Vol. 30, 1977-1978, pp. 843 y ss.

HAMBURGER, Philip: "Law and Judicial Duty", en George Washington Law Review (Geo. Wash. L. Rev.), Vol. 72, 2003-2004, pp. 1 y ss.

HOLT, J. C.: Magna Carta, Cambridge University Press, Cambridge (Great Britain), 1992. 
: "The Ancient Constitution in Medieval England", en The Roots of Liberty (Magna Carta, Ancient Constitution, and the Anglo-American Tradition of Rule of Law), edited with an Introduction by Ellis Sandoz, University of Missouri Press, Columbia (Missouri) and London, 1993, pp. 22 y ss.

KRAMER, Larry D.: "We the Court" (The Supreme Court 2000 Term. Foreword), en Harvard Law Review (Harv. L. Rev.), Vol. 115, 2001-2002, pp. 5 y ss.

MACKAY, R. A.: "Coke-Parliamentary Sovereignty or the Supremacy of the Law?", en Michigan Law Review (Mich. L. Rev.), Vol. XXII, 1923-1924, pp. 215 y ss.

MCGOVNEY, Dudley Odell: “The British Origin of Judicial Review of Legislation", en University of Pennsylvania Law Review (U. Pa. L. Rev.), Vol. 93, 1944-1945, pp. 1 y ss.

MULLETT, Charles F.: "Coke and the American Revolution", en Economica (The London School of Economics and Political Science), No. 38, November, 1932, pp. 457 y ss.

PLUCKNETT, Theodore F. T.: "Bonham's Case and Judicial Review”, en Harvard Law Review (Harv. L. Rev.), Vol. XL, 1926-1927, pp. 30 y ss.

POCOCK, J. G. A.: La Ancient Constitution y el Derecho feudal, Editorial Tecnos, Madrid, 2011.

POUND, Roscoe: "Common law and legislation", en Harvard Law Review (Harv. L. Rev.), Vol. XXI, 1907-1908, pp. 383 y ss.

REY MARTÍNEZ, Fernando: "Una relectura del Dr. Bonham's Case y de la aportación de Sir Edward Coke a la creación de la judicial review", en Revista Peruana de Derecho Público, Año 8, núm. 14, Enero/Junio 2007, pp. 47 y ss.

SHAPIRO, Barbara J.: "Law and Science in Seventeenth-Century England", en Stanford Law Review (Stan. L. Rev.), Vol. 21, 1968-1969, pp. 727 y ss.

SCHWARTZ, Bernard: A History of the Supreme Court, Oxford University Press, New York/Oxford, 1993.

SHEPPARD, Steve (ed.): The Selected Writings and Speeches of Sir Edward Coke, Liberty Fund, Indianapolis, Indiana, 2003, Vol. Two.

SHERRY, Suzanna: "Natural Law in the States", en University of Cincinnati Law Review (U. Cin. L. Rev.), Vol. 61, 1992-1993, pp. 171 y ss.

SMITH II', George P.: "Dr. Bonham's Case and the Modern Significance of Lord Coke's Influence", en University of Washington Law Review (Wash. L. Rev.), (School of Law. University of Washington. Seattle, Washington), Vol. 41, 1966, pp. 297 y ss.

SOSIN, J. M.: The Aristocracy of the Long Robe (The Origins of Judicial Review in America), Greenwood Press, New York/Westport, Connecticut/London, 1989. 
STIMSON, Shannon C.: The American Revolution In The Law (Anglo-American Jurisprudence Before John Marshall), The Macmillan Press, London, 1990.

STONER Jr., James R.: Common law and liberal theory. Coke, Hobbes, and the Origins of American Constitutionalism, University Press of Kansas, Lawrence (Kansas), 1992.

THORNE, S. E.: “Dr. Bonham's Case”, en Law Quarterly Review (L. Q. Rev.), Vol. 54, 1938, pp. 543 y ss.

USHER, Roland G.: "James I and Sir Edward Coke", en The English Historical Review (published by Oxford University Press), Vol. 18, No. 72, October, 1903, pp. 664 y ss.

VEEDER, Van Vechten: "The English Reports, 1292-1865" (I), en Harvard Law Review (Harv. L. Rev.), Vol. XV, 1901-1902, pp. 1 y ss.

VINOGRADOFF, Paul: “Constitutional History and the Year Books", en The Law Quarterly Review(L. Q. Rev.), Vol. XXIX, 1918, pp. 273 y ss.

YALE, D. E. C.: "Iudex in propria causa: An Historical Excursus", en Cambridge Law Journal (Cambridge L. J.), Vol. 33, 1974, pp. 80 y ss.

Artigo recebido em 14 de outubro de 2013. Artigo aprovado para publicação em 17 de outubro de 2013.

DOI: 10.11117/1982-4564.06.21 